\section{Diverse molecular phenotypes of ATP7B protein in Wilson disease: functional insights and therapeutic implications}

\author{
Shashwata Mukherjee* \\ Department of Molecular Biology and Biotechnology, Kalyani Mahavidyalaya, Kalyani, Nadia, West \\ Bengal, India \\ ${ }^{\star}$ Corresponding author, E-mail: shashwata.mkrj@gmail.com
}

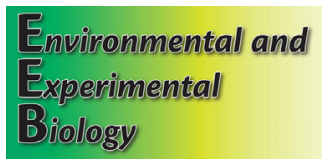

ISSN 2255-9582

UNIVERSITY OF LATVIA

\begin{abstract}
Wilson disease is a rare genetic disease causing copper accumulation due to mutations in the copper transporter protein ATP7B gene. Its varied clinical features result from toxic build-up of the ion primarily in liver and brain. The large number and variety of ATP7B mutations and influence of modifiers are suggested to account for only part of this heterogeneity. Exciting research on functional aspects is gradually elucidating the interesting behaviour of mutant ATP7B under different physiological conditions. Subtle perturbations in its delicate architecture have been shown to affect diverse functional properties of this copper pump. It is possible that compound heterozygotes bearing mutations with two different molecular phenotypes may partially complement each other's defect, giving rise to unpredictable clinical presentation. These have tremendous potential in contributing to the clinical variability. More recent findings indicate the role of interacting partners in modulating the disease phenotype. The present review aims to outline the major strategies for in vitro evaluation of mutant ATP7B protein function, summarize the information on such studies in the literature, and gain new insights on the molecular behaviour and regulation of the protein. The functional consequence of mutations at 86 residue positions was reviewed through search in Pubmed and this information was analysed. A glimpse on studies at the transcription level is also provided. The development of new generation drugs to correct the underlying molecular defect is briefly discussed to emphasize how basic research to elucidate the molecular phenotype can have the potential to usher in the age of precision medicine for this disease.
\end{abstract}

Key words: ATP7B protein, functional study, mutant, missense mutation, Wilson disease.

Abbreviations: 4-PBA, 4-phenylbutyrate; A-domain, actuator domain; AP1S1, adaptor related protein complex 1 subunit sigma 1; APOE, apolipoprotein E; AsPC1, human pancreas adenocarcinoma ascites metastasis cell line; ATOX1, antioxidant 1 copper chaperone; ATP7A/B, ATPase copper transporting 7 alpha/ beta polypeptide; BCS, bathocuproine disulfonate; BDNF, brain-derived neurotrophic factor; BxPC3, human primary pancreatic adenocarcinoma cell line (complex acronym denotes strain); Ccc2p, Cu ${ }^{2+}$-transporting P-type ATPase protein (Saccharomyces cerevisiae); CCS, copper chaperone of superoxide dismutase; CHO, Chinese hamster ovary cell line; COMMD1, copper metabolism domain containing 1; COX, cytochrome c oxidase; Cu/Zn SOD, copper/zinc superoxide dismutase; $\mathrm{DBH}$, dopamine $\beta$-hydroxylase; DRD2, dopamine receptor D2; ER, endoplasmic reticulum; Fet3p, iron transport multicopper oxidase protein (Saccharomyces cerevisiae); GFP, green fluorescent protein; L-DOPA, levo-3,4-dihydroxy-L-phenylalanine; hCTR1, human copper transporter 1; HEK, human embryonic kidney cell line; HeLa, Henrietta Lacks cervical cancer cell line; HepG2, human liver hepatocellular carcinoma G2 cell line; LpCopA, Legionella pneumophila copper-exporting P-type ATPase A; MBD, metal binding domain; MD, Menkes disease; MEDNIK, mental retardation, enteropathy, deafness, neuropathy, ichthyosis, keratodermia; MTHFR, methylenetetrahydrofolate reductase; NBD, nucleotide binding domain; NCI-H358, human Caucasian bronchioalveolar carcinoma cell line (complex acronym denotes strain); NMR, nuclear magnetic resonance; OSIP108, Arabidopsis thaliana-derived oxidative stressinduced decapeptide 108; P-domain, phosphorylation domain; qRT-PCR, quantitative reverse transcription polymerase chain reaction; Rab7A, member of RAS oncogene family of GTP-binding proteins; SERCA, sarco/endoplasmic reticulum Ca ${ }^{2+}$-ATPase; Sf9, Spodoptera frugiperda 9 insect cell line; SLC33A1, solute carrier family 33 member 1; SLC30A10, solute carrier family 30 member 10; TGN, transGolgi network; TM, transmembrane domain;VPS35, vacuolar protein sorting 35 homolog; WD, Wilson disease; WIF-B, rat hepatoma hybrid made by fusing human fibroblasts with rat hepatoma cells.

\section{Introduction}

Genetic defects in the copper transporter ATP7B protein causes Wilson disease (WD) in humans. It is a rare, neglected, inborn error of copper accumulation, depicting autosomal recessive inheritance in pedigrees. WD is a classic example of a Mendelian disorder showing trace metal imbalance, with perplexingly heterogenous clinical expression among patients (Hedera 2019).

ATP7B protein is crucial for the maintenance of physiological copper balance within cells. Ordinarily it resides in the trans-Golgi membrane of hepatocytes 
where it loads cuprous ions into nascent cuproenzyme ceruloplasmin. However, when intracellular copper levels are elevated above cellular needs, ATP7B is directed towards the basolateral membrane to pump out excess copper through bile. Thus, it has both biosynthetic and homeostatic properties. Disruption of either or both properties leads to toxic copper buildup resulting in hepatic and neurologic abnormalities in WD (Lutsenko et al. 2007).

Following identification of the underlying causal gene ATP7B in 1993 (Bull et al. 1993; Petrukhin et al. 1993), researchers have made extensive efforts to elucidate the molecular bases of this disease by genetic and functional approaches. A huge pool of genetic lesions ( 650) have been characterized over the past several years and compiled into a database (Kenney, Cox 2007; Kumari et al. 2018). However, the complex clinical manifestation and extremely diverse mutation spectra has hindered any meaningful genotype-phenotype correlation or gradation of mutational severity (Mukherjee et al. 2014; Medici, LaSalle 2019). Of the identified defects, $60 \%$ are missense, and the others represent nonsense, frameshift and splicesite categories (de Bie et al. 2007a; Squitti et al. 2014). While the latter three categories can be presumed to result in nonfunctional product, mostly due to premature truncation of translation, functional assay assumes primacy for missense mutations, which might actually exert a range of effects. Unfortunately, the functional significance of a substantive fraction of these missense substitutions is yet to be explored. Data on about $1 / 5$ of the variants is currently available, and in a piecemeal manner. Further, not every mechanistic aspect of each mutation has been assessed (Huster et al. 2012; Squitti et al. 2014). Gradually accumulating evidence from in vitro data suggests that functional insights may not only enable appropriate categorization of the deleterious impact of mutation, but has tremendous potential in formulating patient specific targeted and personalized therapies (Braiterman et al. 2014; Kumari et al. 2018). As functional studies are slowly gaining momentum, it has become imperative to accumulate the scattered data to enable projection of a holistic view of all the cellular properties that are impaired due to every single mutation. This would aid in functionally classifying the mutations in order of graded severity, associate the symptoms with the underlying functional category and help in administering appropriate treatment regimen specific for the patient (de Bie et al. 2007a; Braiterman et al. 2014). The above discussion greatly emphasizes the need for systematic curation of newly emerging functional data. This task has not been undertaken for WD in the recent past. Driven by this prerequisite, the primary aim of the present paper, in essence, was to acquire and compile detailed functional data available in published articles on each specific ATP7B mutation, for easy comprehension and fine-grained dissection of the actual impact of mutations on ATP7B protein structure and function.
In perspective, this review briefly glides through the copper homeostatic mechanisms of the cell and undertakes a short stride through the clinical, epidemiological and genetic interface of Wilson disease. Following this, it gradually delves into the various functional studies conducted on the mutant copper transporter ATP7B, whose malfunction causes copper overload and toxicity in humans. An extensive Pubmed database search was carried out to mine and curate the data, which on in-depth critical analysis revealed diverse and interesting molecular properties of the mutant protein with indications for future research avenues.

\section{The dual role of copper as a micronutrient and toxin}

Copper $(\mathrm{Cu})$ is a redox reactive transition metal. It can shuttle between the cuprous (reduced; $\mathrm{Cu}^{1+}$ ) and the cupric (oxidized; $\mathrm{Cu}^{2+}$ ) states. In the human body, this trace element serves as a crucial cofactor for several cuproenzymes like cytochrome c oxidase, lysyl oxidase, peptidylglycine $\alpha$-amidating monooxygenase, tyrosinase, and ceruloplasmin, to name a few. Usually, intracellular copper is present in the reduced form, bound with chaperones. It is oxidized during exit (Lutsenko et al. 2007). The redox reactivity of copper is harnessed to drive a range of life sustaining physiochemical processes involving energy generation, iron acquisition, oxygen transport, signal transduction, etc. (Kim et al. 2008).

However, despite being an indispensable micronutrient whose deficiency could perturb various physiological processes, copper overload can be highly toxic. Due to its property to undergo reversible redox changes, copper can participate in Fenton reaction to catalyze the conversion of a superoxide radical anion $\left(\cdot \mathrm{O}^{2-}\right)$ to a highly reactive and damaging hydroxyl radical $(\bullet \mathrm{OH})$ (Llanos, Mercer 2002; Lalioti et al. 2009):

$$
\begin{gathered}
\cdot \mathrm{O}_{2}^{-}+\mathrm{Cu}^{2+} \rightarrow \mathrm{O}_{2}+\mathrm{Cu}^{+}, \\
\mathrm{Cu}^{+}+\mathrm{H}_{2} \mathrm{O}_{2} \rightarrow \mathrm{Cu}^{2+}+\mathrm{OH}^{-}+\cdot \bullet \mathrm{OH} .
\end{gathered}
$$

The toxicity of copper is further aggravated because it can displace other metal cofactors, like zinc, and also bind and damage proteins (Kim et al. 2008; Prohaska 2008). Hence, within cells, a tightly controlled copper homeostasis system prevents copper imbalance. Copper transporting ATPases, ATP7A and ATP7B, along with an intricate network of chaperones, accomplish these functions. However, the underlying genetic defect leading to metabolic derangement results in hepatic and/ or neurologic abnormalities in the affected individuals (Lutsenko et al. 2007).

The classical and most widely studied genetic disorders of copper imbalance are Menkes disease (MD) and WD. While MD is characterized by copper deficiency due to mutations in ATP7A, defects in ATP7B lead to copper accumulation in WD (Kaler 2013). ATP7A is functionally homologous to ATP7B with $60 \%$ sequence identity (de 
Bie et al. 2007) The pathophysiology of WD will be better appreciated by studying the role of ATP7B in the copper metabolism pathway.

\section{The copper metabolism pathway}

Dietary copper (1 to $3 \mathrm{mg}$ ) is absorbed mostly in the duodenum. Presumably, uptake of the metal into intestinal cells occurs by the high-affinity human copper transporter hCTR1 (Anderson, Frazer 2005; Kuo et al. 2006). From the enterocytes, copper is delivered into blood by $\mathrm{Cu}$-ATPase ATP7A (Monty et al. 2005). Through portal circulation, most of the copper reaches the liver, which is the seat of copper metabolism. Within hepatocytes, copper is distributed to various copper chaperones. In mitochondria, copper binds to the cytochrome c oxidase (COX). In the cytosol, major copper handlers are the metallochaperone copper chaperone of superoxide dismutase (CCS) and ATOX1. CCS transfers copper to the cytosolic radicaldetoxifying enzyme copper/zinc superoxide dismutase $(\mathrm{Cu} / \mathrm{Zn}$ SOD) (Lutsenko et al. 2007). ATOX1, which is a component of the secretory pathway, delivers copper to ATP7B located in the membrane of trans-Golgi network (TGN) of the cell (Hamza et al. 1999). ATP7B derives energy from ATP hydrolysis to pump copper across the golgi membrane into the TGN lumen. Inside lumen, the ferroxidase apoceruloplasmin acquires the metal from ATP7B to form holoceruloplasmin, which is subsequently secreted into the blood stream. When copper level crosses a physiological threshold, ATP7B relocates to vesicles where it sequesters copper (Polishchuk, Polishchuk 2019). The vesicles then migrate and fuse with the basolateral membrane to channel the excess metal for excretion through bile, possibly with the help of COMMD1. In Wilson disease patients, copper transport to the secretory and excretory pathway is impaired due to defective ATP7B (Das, Ray 2006; Gupta et al. 2010; Lutsenko 2014). Hence, excessive $\mathrm{Cu}$ accumulates in the liver with insignificant excretion through bile. Apoceruloplasmin is rapidly degraded and the level of holoceruloplasmin in serum falls greatly (Langner, Denk 2004; Behari, Pardasani 2010).

The tissue specific expression profile of copper ATPases indicates that ATP7A and ATP7B may have both distinctive and overlapping roles. Enterocytes express only ATP7A, while hepatocytes exclusively express ATP7B. Several tissues like brain, placenta, developing kidney, mammary gland, eye, lung express both $\mathrm{Cu}$-ATPases. Many studies suggest that the two ATPases can have overlapping function (Lutsenko 2007). Two effective assays to evaluate ATP7B function have been developed based on this observation, and this will be described in subsequent sections. However, the observation that the two transporters do not often complement each other in tissues also underlines their distinct physiological engagements. However, the reason for this distinctiveness is still not well understood (Lutsenko 2007).

\section{Wilson disease - clinical and epidemiological considerations}

WD patients present with hepatic, neurologic, psychiatric or mixed symptoms. Some patients also show atypical features (Aggarwal, Bhatt 2020). Classical diagnostic indications include copper deposition in the descemet's membrane of cornea (Kayser-Fleischer Ring), low serum ceruloplasmin $\left(<20 \mathrm{mg} \mathrm{dL}^{-1}\right)$ and high 24 -h urinary copper excretion $\left(>100 \mu \mathrm{g} 24 \mathrm{~h}^{-1}\right)$. Although biochemical abnormalities are present from birth, the clinical symptoms do not usually appear earlier than the late first or second decade of life (12 to 23 years; Das, Ray 2006). In many instances however, WD patients with classic neurologic or hepatic findings can be diagnosed easily. Unfortunately, the typical symptoms of WD may be absent in nearly half of all patients (Steindl et al. 1997; Ferenci, Roberts 2012). Varied age-at onset of symptoms and extremely heterogenous clinical manifestation, often overlapping with other neurological or hepatic conditions, and limited opportunity and experience of clinicians in dealing with patients having rare disorders make diagnostic workup a challenge. Despite being a genetic disorder, it is treatable. Patients require life-long de-coppering with copper chelators like D-penicillamine, trientine etc. and can lead mostly normal life only if detected at an early stage (Ferenci, Roberts 2012). Various aspects of diagnosis and clinical management of WD have been described in a number of recent articles (Członkowska et al. 2018; Roberts 2018; Aggarwal, Bhatt 2020; Moini et al. 2021).

The estimated global disease prevalence is $1 / 5000$ to $1 / 30000$ with a carrier frequency of 1/90 (Thomas et al. 1995; Figus et al. 1995). This estimation is outdated and does not include objective representation from several populations. A more recent estimate from Britain points towards a possible higher prevalence of 1/7026 (Coffey et al. 2013). According to a current study, while the estimated prevalence based on genetic data is $1 / 2400$, the clinical prevalence is $1 / 20000$ (Wallace, Dooley 2020). The authors propose that not all variants of ATP7B are clinically penetrant and this variable penetrance is the underlying reason for stark discrepancy in prevalence outcome. Hence, one needs to observe caution when assigning causality to ATP7B mutations. Although clinical and genetic aspects of WD in the Indian population have been explored by a handful of research groups in this country (Mukherjee et al. 2014), appropriate epidemiological data curating disease burden in our population is unfortunately not available.

\section{The mutation spectra of Wilson disease}

The ATP7B gene is $\sim 80 \mathrm{~Kb}$ long with 21 exons (chromosomal location 13q14.3-q21.1, ENSEMBL gene ID ENSG00000123191, NCBI RefSeq NG_008806.1, Genebank No NM_000053.4). Mutation screening revealed more than 650 defects spanning almost the entire length of 
the ATP7B gene (Wilson disease mutation database, http:// www.wilsondisease.med.ualberta.ca/database.asp; Squitti et al. 2014) and many new continue to be reported. Of all the mutations, most are rare and restricted in single families. However, some are more common and account for a large fraction of the patient pool. Further, the prevalent and rare mutations depict population-specific geographical distributions, which are largely non-overlapping (Ferenci 2006; Behari, Pardasani 2010; Gomes, Dedoussis 2016). Haplotype analysis suggests that the occurrence of regionspecific common mutations is due to a founder effect (Petrukhin K et al. 1993; Figus et al. 1995). Rare mutations usually arise spontaneously and can be considered to be of more recent origin owing to the low frequency.

In India, p.C271X is the most prevalent mutation (Gupta et al. 2007). Other common mutations include p.E150H-fs, p.P767P-fs, p.A1049A-fs, p.G1101R, p.G1061E, p.A1241V, p.N1270S, and p.L1299F (Aggarwal et al. 2013; Mukherjee et al. 2014). The common mutations among Caucasian (Vrabelova et al. 2005), Brazilian (Deguti et al. 2004), Sardinian (Loudianos et al. 1999) and Saudi Arabians (Majumdar 2003) are p.H1069Q, p.A1135Q-fs, c.-427_c.441del15, p.Q1399R respectively. The mutation p.R778L is the prevalent defect in Japan, Taiwan and China (Nanji et al. 1997).

\section{The phenotypic spectra of Wilson disease and influence of modifiers}

Clinical manifestation of WD is extremely heterogenous. Patients may range from being asymptomatic to completely debilitated and bound to bed. Variable degree of hepatic involvement ranging from sub-clinical jaundice to fulminant hepatic failure requiring liver transplantation has been reported (Hedera 2019). Neuro-psychiatric presentation shows extrapyramidal abnormalities like dystonia, dysarthria, drooling, parkinsonism, behavioural abnormality, etc (Mukherjee et al. 2014). Patients may also present with mixed symptoms with variable endophenotypes. Even after a century of the clinical description of WD by neurologist Dr. Samuel Alexander Kinnier Wilson (Wilson 1912), it remains unclear as to why some Wilson disease patients develop predominantly hepatic disease while others develop neurological disease (Hedera 2019; Aggarwal, Bhatt 2020). The genotypephenotype correlation has been the subject of investigation in several studies. However, efforts to ascribe a specific mutation to a particular phenotype have met with limited success. (Mukherjee et al. 2014; Lutsenko 2014). Such correlation studies have been complicated due to the presence of a large number and diversity of mutations detected in the ATP7B gene, larger number of compound heterozygotes, limited number of patients available for analysis and heterogenous clinical manifestation, even between sibs having identical ATP7B mutation background.
(Barada et al. 2007; Kegley et al. 2010).

The remarkable phenotypic variability and detection of cases with extra-wilsonian features has led researchers to investigate the involvement of epigenetic alterations, as well as additional genetic and/or environmental factors as modifiers of the phenotype (Lutsenko 2014; Medici, Weiss 2017; Medici, LaSalle 2019). Supposing a possible crosstalk between different metal imbalance disorders, genes of the copper and iron metabolism pathways and those implicated in other hepatic and/or neurological disorders have been studied. Genetic association studies involving polymorphisms of COMMD1 (Lovicu et al. 2006; de Bie et al. 2007b; Gupta et al. 2010), ATOX1 (Lee et al. 2011), APOE (Roy et al. 2018), MTHFR (Gromadzka et al. 2011), DBH (Roy et al. 2019), BDNF, and DRD2 genes (Roy et al. 2018) have been undertaken. However, findings of one study are either not replicated in other cohorts or remain to be tested in larger data sets. Hence, despite indications of their role in imparting protection or risk to WD manifestation and prognosis, their convincing influence as modifier loci in dictating WD endophenotypes has remained elusive.

To complicate matters further, diseases mimicking the WD phenotype have been described recently. Molecular defects in SLC33A1, CCS, AP1S1, SLC30A10 genes can cause Huppke-Brendel syndrome, CCS deficiency, MEDNIK syndrome and manganese imbalance, respectively (Quadri et al. 2012; Kaler 2013). It appears reasonable to include these genes in the window of suspicion and explore them for their putative role in imparting WD features by novel pathophysiological mechanisms (Aggarwal, Bhatt 2020).

As evident from the previous discussion, many investigations have been done to decipher the underlying genetic basis of heterogenous presenting symptoms. However, the challenge persists. In tune with this experience, emerging functional evidence depicting the effect of mutation on the ATP7B protein phenotype is equally interesting and diverse. We shall start exploring this diversity by first appreciating the delicate architecture of the Wilson disease protein, ATP7B.

\section{The Wilson disease protein ATP7B (Uniprot P35670)}

ATP7B is a member of the cation-transporting P1B-type ATPase family, a group of proteins that pumps metal ions into and out of cells by deriving energy from ATP hydrolysis (Gourdon et al. 2011; Gourdon et al. 2012). Being a large (165 Kda) membrane protein (Squitti et al. 2014), its crystal structure is currently not available. It has several putative functional domains predicted based on nuclear magnetic resonance (NMR) studies of partial polypeptide segments of soluble cytosolic domains and homology modelling against SERCA Ca ${ }^{2+}$-ATPase (Achila et al. 2006, Dmitriev et al. 2006; Banci et al. 2009; Barry et al. 2010). A more recent crystal structure of bacterial P1B type ATPase LpCopA has aided the annotations further (Gourdon 
et al. 2011; Gourdon et al. 2012; Schushan et al. 2012). ATP7B has six N-terminal copper binding domains (metal binding domain, MBD; each with $\mathrm{CxxC}$ motif), and eight transmembrane domains (TM) with Cys-Pro-Cys (CPC) motif in TM6 forming the internal copper binding site (Fig. 1). The TMs are connected by luminal and cytosolic loops. The loop between TM6 and TM7 harbours the ATP binding region composed of the nucleotide-binding (NBD) (with SEHPL motif) and phosphorylation (P) domains (with DKTG motif) (Lutsenko et al. 2007; Barry et al. 2010). The NBD binds and hydrolyzes ATP. This leads to phosphorylation of the P-domain at its invariant Asp acid residue in the DKTG motif. The NBD and P-domains work in coordination to alter the conformation of the transporter facilitating copper channelling. An actuator (A) domain between the TM4/5 bearing TGE motif with phosphatase activity resets the transporter to its initial conformation following copper release to the other side of the membrane (de Bie et al. 2007a).

In summary, the ATP7B catalytic cycle constitutes several steps: (i) copper is recognized by the pump followed by binding to the TM6 intra-membrane ion binding site, (ii) ATP binds to the nucleotide-binding domain (NBD), (iii) ATP is hydrolyzed with concomitant transfer of $\gamma$-phosphate of ATP to the invariant aspartic acid residue in NBD, (iv) the ion is translocated, and (v) the NBD is dephosphorylated by the A-domain. (Lutsenko et al. 2007; de Bie et al. 2007a; Lutsenko et al. 2008; Barry et al. 2010). All of the soluble domains are cytosolic. The NBD and $\mathrm{P}$-domains are catalytic while the rest are regulatory in nature (Lutsenko et al. 2008; Yu et al. 2017).

Mutations often upset this delicate structural organization of ATP7B. This impairs the coordination and coupling of the domains required for pumping action. The genetic lesions might perturb one or more functional aspects: (i) copper transport across the membrane, (ii) cuproenzyme biosynthesis, (iii) catalytic ATPase activity, (iv) localization and/or trafficking, (v) post translational modifications and, (vi) communication with interacting partners. It has also been found that these aspects, although studied separately, are rather inter-dependent (de Bie et al. 2007a). Mutations that diminish substrate affinity and decrease rate of conformational transitions without totally abrogating protein function may have a partial effect on the molecular phenotype (Huster et al. 2012). Emerging functional evidence, as discussed in subsequent sections, suggests that the ATP7B variants show diverse functional properties with tremendous potential to contribute to the phenotypic heterogeneity in WD.

\section{Major strategies for in vitro evaluation of mutant- ATP7B function}

Several different functional approaches utilizing yeast, mammalian and insect cell lines, have been developed to assess the effect of mutations on ATP7B protein function.

The ATP7B yeast homologue in Saccharomyces cerevisiae Ccc $2 p$ is located in the Golgi membrane of yeast cells. It delivers copper to yeast ceruloplasmin homologue Fet3p, a high affinity copper-dependent iron transporter. Holo-Fet3p, located in the membrane of yeast cells enables them to take up iron from media under iron-limited conditions. However, if the Ccc2p gene is deleted, yeasts are unable to grow under limiting conditions. ATP7B has been found to functionally complement the absence of normal Ccc2p. Hence, ectopic expression of mutant ATP7B in yeast allows for an easy assessment of their biosynthetic function (Hsi et al. 2008; Luoma et al. 2010). There are, however, two caveats. As yeasts grow normally at $30{ }^{\circ} \mathrm{C}$, mutants that would otherwise unfold at $37^{\circ} \mathrm{C}$ in mammalian cells,

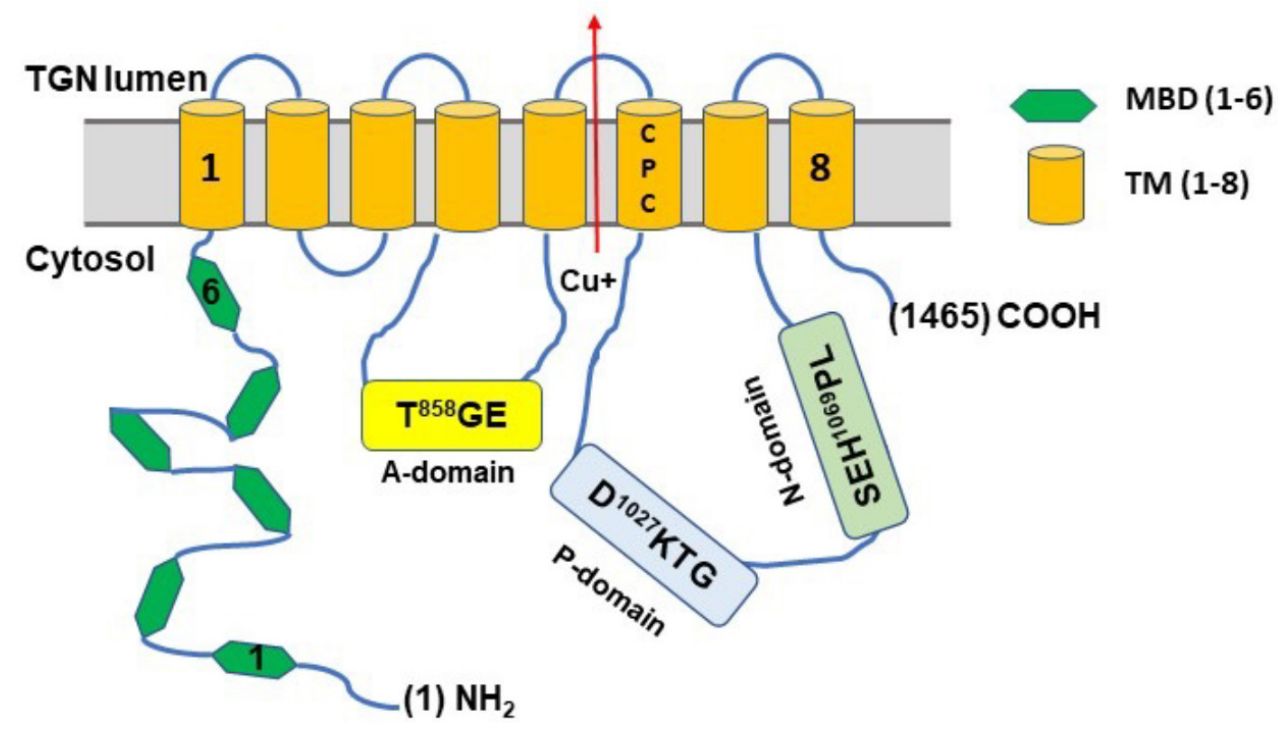

Fig. 1. Simplified domain architecture of ATP7B. A, actuator domain; MBD, metal binding domain; N, nucleotide binding domain; P, phosphorylation domain; TM, transmembrane domain. See text for details. Figure adapted and modified from Kumari et al. 2018. 
are stable at that lower temperature. Also, mutants with residual copper transport activity can completely rescue the yeast phenotype. Hence, these results must be interpreted with caution (Huster et al. 2012).

Tyrosinase activation assay is another strategy to analyze the biosynthetic activity of ATP7B mutants. In Menkes disease, the copper transporter ATP7A is mutated. ATP7A is known to load copper to tyrosinase. Active tyrosinase enzyme catalyzes the transformation of levo-3,4dihydroxy-L-phenylalanine (L-DOPA) to a black pigment DOPA quinone in the melanin biosynthetic pathway. The Menkes patient skin fibroblast cell line lacks active copper-ATPase, as ATP7A is non-functional and ATP7B is not expressed (Lutsenko et al. 2007). In absence of copper loading, tyrosinase remains inactive. Interestingly, heterologous expression of ATP7B can restore tyrosinase activity, resulting in the formation of black pigment in culture dishes, in presence of substrate (Guo et al. 2005). This ability of ATP7B to metallate apo-tyrosinase has been utilized to explore the effect of ATP7B mutations (Braiterman et al. 2009; Hasan et al. 2012)

Researchers have also developed in-vitro copper transport assay by using microsomal vesicles derived from Sf9 insect cell lines (Tsivkovskii et al. 2002). They expressed wild type and mutant ATP7B in Sf9 insect cells by infecting them with recombinant baculovirus carrying desired inserts. Microsomal vesicles were prepared from membrane fractions that served as a model for TGN vesicles. Copper transport was assessed by measuring accumulation of ${ }^{64} \mathrm{Cu}$ in the vesicles in presence and absence of wild type and mutant ATP7B (Huster D et al. 2012). Again, when insect cells are grown at $27^{\circ} \mathrm{C}$, mutants that are misfolded at 37 ${ }^{\circ} \mathrm{C}$ may show some residual function on account of greater folding and stability at a lower temperature.

The catalytic activity of ATP7B has been evaluated by using a Sf9 cell line as well. Membrane fractions containing ATP7B were incubated with radioactive $\left[\gamma^{-}{ }^{32} \mathrm{P}\right]$ ATP. The ability of ATP7B to form a phosphorylated intermediate was checked further to confirm nucleotide binding, hydrolysis, autophosphorylation and hence the activity of mutants (Huster et al. 2012).

Probably the most widely studied aspect of ATP7B is its localization and trafficking in response to different levels of copper in media. Mammalian cell lines like HepG2 (Huster et al. 2003), HEK (Huster et al. 2012), WIF-B (Braiterman et al. 2009), CHO (Forbes, Cox 2000) etc., have been used for this purpose. Recombinant vectors with green fluorescent protein (GFP) tagged ATP7B sequence inserts were transfected in these cells. The co-localization of wildtype and mutant ATP7B against organellar markers (like TGN38, calnexin), under conditions of basal $(0.02 \mu \mathrm{M})$ and elevated media copper (10 to $200 \mu \mathrm{M}$ ) have been studied to elucidate the normal location, and anterograde movement of the protein in response to varied copper load (Braiterman et al. 2009; Gupta et al. 2011). The retrograde movement of ATP7B from the cell membrane to TGN was studied by depleting the media of copper by addition of chelator bathocuproine disulfonate (BCS) (Braiterman et al. 2009; 2011).

Cells lines BxPC3, AsPC1, HeLa, NCI-H358, and CHO lacking inherent ATP7B expression have been employed to test for intracellular copper accumulation, activity of secreted ceruloplasmin in media and cell viability by transfecting them with various ATP7B mutants under different media copper concentrations (Kumari et al. 2018). Cell lines with stable expression of mutant ATP7B have also been studied for various parameters like copper tolerance, apoptosis, drug response, protein stability, and trafficking (Chandhok et al. 2016)

Given the diverse functional properties of ATP7B, no single technique is sufficient to throw light on all the functions. Acknowledging the fact that every strategy has some limitations, they have been successful in providing valuable insights into the impact of mutations on protein function.

\section{Functional studies have an edge over genetic or in silico approaches}

Assigning causality to a sequence variant is extremely important for WD owing to its diagnostic significance. This is because, due to complex overlapping phenotypic presentation and misleading biochemical indications hovering along borderline in younger age groups, genetic testing is considered as a gold standard for confirmatory diagnosis (Aggarwal et al. 2013; Aggarwal, Bhatt 2020). In general, the effect of nonsense, frameshift or splice-site mutations can be gauged with confidence as they almost always lead to premature termination of translation producing non-functional protein product. However, there is no straight-forward route to ascertain the impact of missense mutation that may lead to a spectrum of consequence, from being functionally silent to severely deleterious (Mukherjee et al. 2014).

For any novel sequence variant, geneticists often resort to control group screening. This comparison group consists of age, gender and ethnically-matched healthy individuals without any family history of genetic disease. By definition, absence of a variant in 50 control individuals (i.e., 100 alleles for biallelic locus) qualifies the variant to be called as deleterious (Karki et al. 2015). However, subject recruitment in a control group is often less stringently carried out. Also, extremely rare innocuous alleles may get wrongly identified as damaging mutations simply because of its absence in a small group of shoddily selected individuals. Another parallel approach is to evaluate a mutation by multiple in silico mutation analysis tools, which utilize different algorithms. The probability outcome from individual tools is pooled to generate a cumulative probability score for a mutation to be deleterious and then a consensus is reached 
(Squitti et al. 2014). This technique is quite handy and gives greater confidence in interpreting a mutation. However, the challenge is to set a cut-off in the probability score (between 0 and 1) in order to categorise the variant as damaging or benign. Mutations with ambiguous scores in the range of 0.5 to 0.7 are difficult to classify (Squitti et al. 2014). For a protein like ATP7B with diverse functional properties, the evaluation may become all the more complicated, unless validated by functional studies. Hence, several investigators have explored the effect of missense mutations on the normal protein function (de Bie et al. 2007a; Huster et al. 2012).

\section{Glimpses from the structure-function relationship in the backdrop of sub-cellular localization of ATP7B protein}

A compilation of selected mutations affecting 86 residue positions, retrieved from a Pubmed search (keyword ATP7B), was mostly comprised of studies on missense variants (documented in Appendix 1). The various points in the cellular itinerary of ATP7B that can be perturbed by different mutations are depicted in Fig. 2. As evident from the illustrations (Appendix 1 and Fig. 2), ATP7B mutations might partially or completely interfere with one or all of the behaviours described previously, leading to a variety of consequences. The following are depicted in Fig.
2. (i) The grossly misfolded ATP7B mutants are retained by the ER quality control machinery and hence they show ER localization. However, mutants attaining near-normal conformation/ stability may slowly slip through the ER gate-keepers to reach TGN. Mutants may also lose TGN retention capacity and assume vesicular localization after crossing the ER checkpoint, irrespective of copper levels. Altered ATP7B with near-normal conformation reaching $\mathrm{TGN} /$ vesicles might have impairment in other functions. (ii) Despite reaching TGN, mutant ATP7B might fail to perform its biosynthetic and homeostatic functions with optimal efficiency. The protein might have compromised copper sensitivity, copper binding and transport across membrane and/ or steps in the catalytic cycle and have variable outcome. (iii) Diminished copper transport rate across the membrane may directly affect cuproenzyme biosynthesis due to rapid degradation of apoenzymes without a metal cofactor. (iv) Mutant ATP7B might be unresponsive to elevated copper levels and fail to transit out into vesicles from TGN and move towards the cell membrane. In absence of anterograde movement, excess copper would not be pumped out from the cells. (v) In contrast, mutant ATP7B depicting constitutive vesicular appearance might be unable to sense depleting copper levels and fail to recycle back to TGN (retrograde movement).

Mutations might have variable effect on one or all of the properties leading to cellular copper accumulation

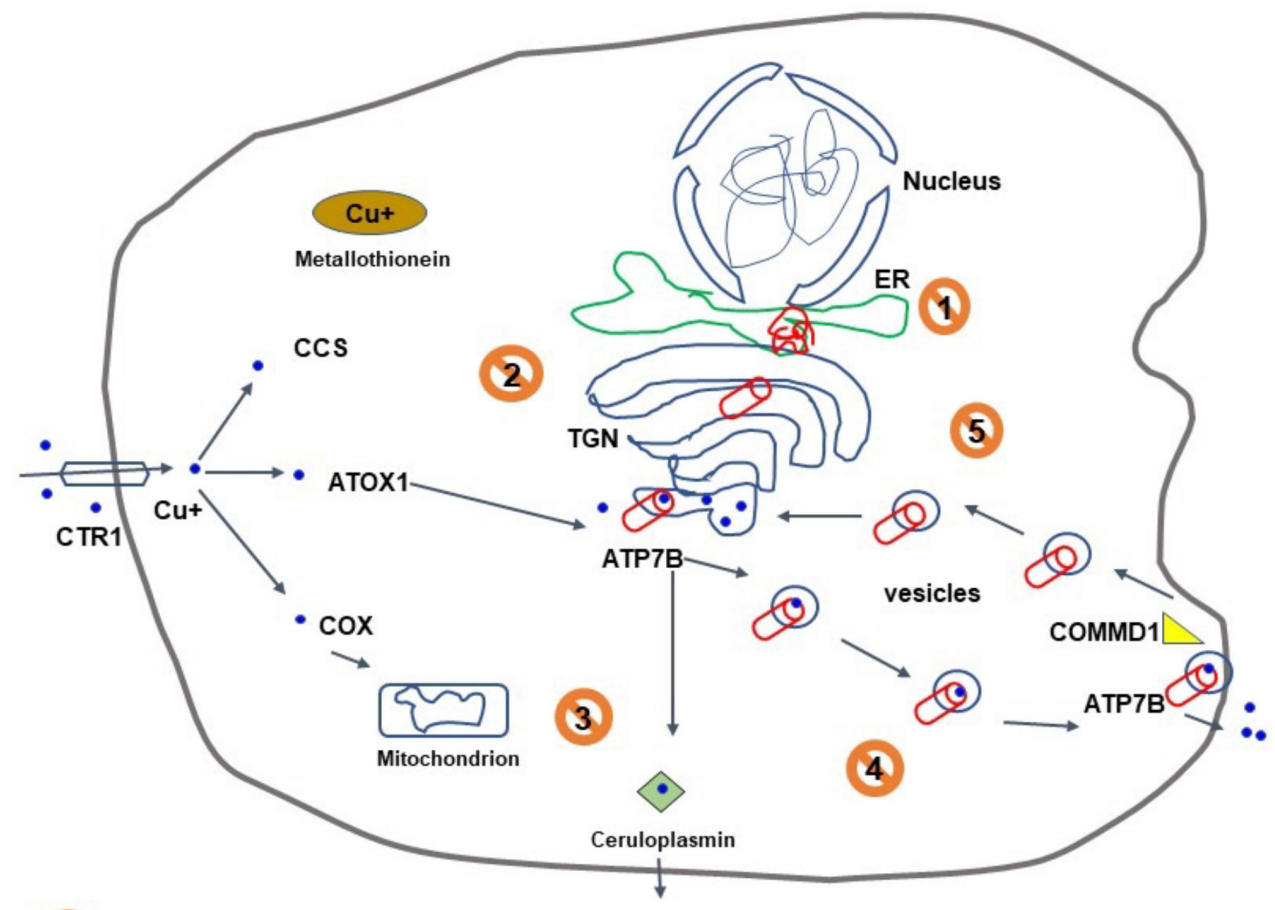

Mutations may lead to functional perturbations at several transit points

Fig. 2. The copper homeostatic pathway showing points of perturbation in ATP7B itinerary, caused due to Wilson disease mutations. COX, cytochrome c oxidase; CCS, copper chaperone of superoxide dismutase; ER, endoplasmic reticulum; TGN, trans-Golgi network. See text for detailed explanation on perturbed transit points 1 to 5. Figure adapted and modified from Madam Curie Bioscience database at http://www.ncbi.nlm.nih.gov/books/NBK6381. 
and precipitation of the disease (Appendix 1). Before we examine the key findings from functional studies, a revisit to the structure-function relationship of ATP7B protein in the backdrop of its strategic sub-cellular location, will be important to better appreciate the context.

In a low copper level environment, ATP7B is located mostly in the last TGN compartment, with scarce vesicular presence. At elevated copper levels, abundance of ATP7Bpositive vesicles increases. They migrate towards the plasma membrane, and fuse with it to release their contents (Polishchuk, Lutsenko 2013; Gupta et al. 2018).

TGN localization offers two definite advantages to ATP7B. First, its lower pH environment allows ATP7B to easily release and deliver copper to the cuproenzymes. And second, TGN is the Golgi exit port for cargo proteins. This enables rapid transit of ATP7B to vesicles without having to tread through the whole Golgi stack during rising copper concentrations (Polishchuk, Lutsenko 2013; Polishchuk, Polishchuk 2019). Hence, mutations affecting normal localization and trafficking interfere with normal function of the protein.

Again, the trafficking and pump activity is governed by the phosphorylation status of the protein. This in turn is modulated by copper. Two major ways of phosphorylation is reported for ATP7B. During catalytic self-phosphorylation, a transient phosphorylated intermediate is formed when the $\gamma$-phosphate from ATP is transferred to the invariant aspartic acid residue in the DKTG motif of NBD. This constitutes the central step in the catalytic cycle. The precondition for this reaction is the binding of copper to the membrane portion of the enzyme. Copper release from this internal site stimulates dephosphorylation (de Bie et al. 2007a; Barry et al. 2010; Pilankatta et al. 2011; Hasan et al. 2012)

In addition to catalytic self-phosphorylation, ATP7B may undergo kinase mediated hyper-phosphorylation of several serine residues at copper elevated conditions. This acts as a traffic signal (Hasan et al. 2012). Experimental evidence suggests that under basal conditions, the $\mathrm{N}$-terminal MBDs are only partially occupied by copper. Also, only a few serine residues are phosphorylated by kinases. At this stage, the pump assumes a very compact structure such that the intramembrane copper binding site at TM6 is only partly accessible. Also, the MBDs are so folded such that they become involved in an autoinhibitory engagement with the NBD. The pump action is thus just optimal to transport copper into TGN lumen (Hasan et al. 2012).

As copper levels rise, more of the metal binding sites are occupied by the ion. This induces substantial change in the compact conformation of the protein so that the negative interdomain interaction is evaded. TM6 is significantly exposed. The pump becomes more dynamic due to its reorganization. This enhances its transport activity. The increased pumping action saturates the copper acceptor proteins. As a consequence, copper release from ATP7B into TGN lumen is inhibited. Subsequently, ATP7B is self-saturated with copper and assumes an exit-ready conformation, poised to leave the TGN (Hasan et al. 2012). In this condition, kinase mediated phosphorylation is also enhanced, which further stabilizes this trafficking compatible state. Now, ATP7B is able to interact with the cellular anterograde trafficking machinery and relocate to vesicles. (Hasan et al. 2012; Polishchuk, Polishchuk 2019). Copper depletion triggers dephosphorylation and ATP7B returns to TGN from vesicles (retrograde movement). Thus, alterations in the precise conformation/inter-domain interactions in ATP7B can be brought about by a change of phosphorylation status. This may further permit or inhibit its communication with post-Golgi trafficking machinery (Braiterman et al. 2009; Pilankatta et al. 2011; Hasan et al. 2012). A trafficking-ready copper saturated state has been created by engineered mutations. This conformation was found to shift the basal level localization mutants from TGN to vesicles, independent of copper induction (Hasan et al. 2012).

Parameters other than phosphorylation status also modulate the protein's copper responsiveness. The junction of TM8 and the C-terminal tail plays a crucial role in retention of ATP7B in TGN (in low copper) and protein stability. A C-terminal tri-leucine (L1454-56) signature has been identified. It was found to be essential for ATP7B retrieval back to TGN from its dispersed vesicular localization at low copper levels (retrograde trafficking) (Braiterman et al. 2011; Polishchuk, Lutsenko 2013).

\section{A survey of functional studies on ATP7B mutants}

As we scan from the N to Cterminal of the protein, interesting observations are gleaned from these studies (Appendix 1). Some mutations in the N-terminal leader sequence (ahead of the MBDs) have shown normal biosynthetic activity. However, they are constitutively missorted to the basolateral membrane (Braiterman et al. 2009). Two mutants (p.A595T and p.R616W) that affect MBD6 showed normal TGN localization but reduced copper transport rate (Li et al. 2019; Roy et al. 2020). A mutant p.S653Y (MBD6/ TM1) was copper transport competent but had trafficking defective behaviour (Braiterman et al. 2014).

Varied observations have been made from functional studies of mutants in the transmembrane segments (TM). The most frequent east Asian mutation p.R778L is extensively mislocalised in endoplasmic reticulum (ER). This mutation and another variant at this position, p.R778Q, has an only partial yeast rescue phenotype (Forbes, Cox 1998; 2000; Zhu et al. 2015). The frequent Korean mutation p.A874V showed partial copper transport activity and was mislocalized (Huster et al. 2012). However, several other variants showed normal TGN localization despite having compromised copper transport activity. 
Now let us turn to the nucleotide binding domain (NBD) of ATP7B. The most common missense mutation in the eastern Indian patient population, p.G1061E, and its counterpart from western region of India, p.G1101R, are located in this domain. Researchers found these mutants to be trapped in ER, presumably due to gross misfolding. They also lacked transport activity (Roy et al. 2020). The most common missense mutation in the European population, p.H1069Q, was also extensively studied by several groups. Although it is mislocalised in ER, and has low copper transport activity in mammalian cells, it can complement the yeast phenotype (Iida et al. 1998; Hsi et al. 2008; Luoma et al. 2010). Dmitriev et al. (2006) showed that the residues 1061-1069, 1099-1106 and 1146-1153 contribute to maintain appropriate configuration of the ATP7B nucleotide binding domain. They are also vital for ATP binding. This finding is consistent with the information that p.H1069Q has greatly diminished ATP binding and hydrolysis and extensive mislocalization in ER (de Bie et al. 2007a). However, at a lower temperature $\left(28^{\circ} \mathrm{C}\right)$, the mutant protein attained partial TGN localization. Dmitriev et al. 2011 suggested that it is a temperature-sensitive defect resulting in abnormal protein folding leading to degradation. It is tempting to speculate that the mutations p.G1101R and p.G1061E might follow a similar cellular event as well.

However, not all mutations in NBD lead to misfolding and ER retention. Catalytic inactivity appears to be the primary cause of protein malfunction for mutations in this domain. Also, a few lesions perturbing the same amino acid residue show differing functional outcome as well (Appendix 1).

Lesions located in TM8 and the C-terminal tail have also been investigated. While several of them showed normal or partially compromised cuproenzyme biosynthesis, their normal localization varied. Some assumed TGN localisation while others demonstrated diffused cytoplasmic or vesicular appearance (Appendix 1). The mutation p.S1362A showed a localization competent but trafficking unresponsive behaviour. p.S1426I was found to be trafficking competent but with copper transport compromised behaviour (Roy et al. 2020). Interestingly, this mutant was found to show a mirror-image molecular phenotype w.r.t. p.S653Y (MBD6/TM1) where exactly the reverse event was observed (Braiterman et al. 2014). This immediately suggests that probable mutations with residual copper transport activity, but defective in localization/ trafficking, may complement each-other's lacunae and give rise to a near-normal phenotype in a compound heterozygous individual.

Apparently, innocuous variants and non-synonymous polymorphisms have also been implicated in attributing partially detrimental effect. Surprisingly, non-diseasecausing variants (p.V456L, and p.K832R) have been found to decrease ATP7B activity (Huster D et al. 2012; McCann et al. 2019). The polymorphic variant p.G875R showed a 'shifting normal/mutant localization' phenotype depending on the amount of copper in the growth medium (Gupta et al. 2011). The above observations highlight the diverse consequences that missense mutations might have on the protein function. All of the cellular properties of the protein should be tested to obtain a complete functional profile of each variant.

An attempt was made here to summarise the apparent relationships between the molecular phenotype and affected protein domain (Table 1). From the table it is clear that mutations affecting the regulatory and catalytic domains may confer varied cellular properties to the mutant protein. Excepting the C-terminal tail, which seems to be mainly involved in localization and trafficking, it is difficult to attribute any specific molecular phenotype to a definite domain.

\section{Exploration of mutations at transcriptional level points to new mechanisms of pathogenesis}

There is a preconceived idea that while synonymous variants are rather innocuous, frameshift mutations create a premature stop codon generating truncated non-functional product. However, at least for a few such

Table 1. Relationship between molecular phenotype and affected protein domain. All cellular properties are not evaluated against all the domains. A single mutation might affect one or all properties. The impact might be partial or complete

\begin{tabular}{|c|c|c|c|c|c|}
\hline \multirow{2}{*}{$\begin{array}{l}\text { Aberrant molecular phenotype of } \\
\text { mutant ATP7B }\end{array}$} & \multicolumn{5}{|c|}{ Affected domain } \\
\hline & $\begin{array}{l}\text { Metal binding } \\
\text { domain (MBD1- } \\
6 \text { 6) }\end{array}$ & $\begin{array}{c}\text { Transmembrane } \\
\text { domain (TM1- } \\
\text { 8) }\end{array}$ & $\begin{array}{l}\text { Actuator (A)- } \\
\text { domain }\end{array}$ & $\begin{array}{c}\text { Nucleotide } \\
\text { binding and } \\
\text { phosphorylation } \\
\text { domain (NBD) }\end{array}$ & C-terminal tail \\
\hline $\begin{array}{l}\text { Localization and/or trafficking } \\
\text { mutant }\end{array}$ & N-term, MBD1, & TM1, TM4, TM6 & Yes & Yes & Yes \\
\hline $\begin{array}{l}\text { Defective copper transport and/or } \\
\text { cuproenzyme biosynthesis }\end{array}$ & MBD6 & TM2, 4,8 & Yes & Yes & Not reported \\
\hline $\begin{array}{l}\text { Impaired catalysis and/or } \\
\text { dephosphorylation }\end{array}$ & MBD1, 6 & TM4 & Yes & Yes & Not reported \\
\hline Misfolded and/or unstable & MBD1, 6 & Not reported & Yes & Yes & Not reported \\
\hline
\end{tabular}


mutations, very recent findings contest this notion. Minigene assays, quantitative reverse transcription polymerase chain reaction (qRT-PCR), northern blot and copper transport assays demonstrated that while synonymous variants in ATP7B may cause disrupted RNA splicing (Zhou et al. 2021) and exon skipping (Wang et al. 2018), effect of the premature stop codon due to a frame shift mutation may be overcome by bypassing nonsense mediated mRNA decay through translation re-initiation (Stalke et al. 2019). Since few observations contrary to the expected outcome have been reported, this should act as a caveat while applying a generalized interpretation regarding functional consequence of such variants without appropriate investigation.

\section{Correction of molecular defect at the protein level indicates budding therapeutic avenues}

Conventional treatment of WD relies on copper chelators such as D-penicillamine, trientine and others. Zinc salt is also administered to induce intestinal metallothionine expression, which would sequester the ion in the intestinal cell, thus inhibiting delivery into blood. The chelators often cause dramatic mobilization of accumulated copper, leading to hepatic and neurological deterioration (Purchase 2013). Owing to side effects, poor prognosis and unresponsiveness of some patients to existing therapy, investigators are always in the lookout for new drugs. In this context, next generation de-coppering agents such as $\alpha$-lipoic acid (Smirnova et al. 2018), bacterial copper binding protein methanobactin (Erlinger 2016; Lichtmannegger et al. 2016), and plant decapeptide OSIP108 (inhibitor of $\mathrm{Cu}$-induced apoptosis) (Spincemaille et al. 2014) are currently being investigated as probable candidates for WD treatment. This chelation approach, although promising and time tested, has focussed on managing the consequence (copper overload) rather than ameliorating the cause. With gradual accumulation of functional data, attempts to rectify the underlying molecular defect also picked up pace. Pharmacological chaperones curcumin and 4-phenylbutyrate (4-PBA) were found effective in increasing protein levels for misfolded mutants with infirm structure and reduced stability. Presumably, 4-PBA increases the abundance of heat-shock proteins and promotes protein folding (van den Berghe et al. 2009; Kumari et al. 2018). The mechanism of curcumin action is not well understood. The chemotherapeutic drug cisplatin stabilizes the partly folded mutant ATP7B by mimicking a copper bound state under low copper milieu (Gupta et al. 2011). The pharmacologically active peptide small heat-shock protein $\alpha B$-crystallin was shown to correct mislocalization and trafficking of the ATP7B H1069Q Caucasian mutant (Allocca et al. 2018). These findings highlight the idea that better understanding of the functioning of the copper pump could be coupled with exploration of novel therapeutic avenues, which holds much hope for improved treatment modalities in the future.

\section{Conclusions and future prospects}

In conclusion, the above deliberation allowed us to have a glimpse of the influence of mutations on the multifaceted molecular phenotype of ATP7B from diverse perspectives, thereby providing cues for further investigations. A detailed functional exploration of the effect of missense variants on various properties of the altered protein by utilizing an array of different methods is warranted. This would lead to more in-depth analysis of the probable effect of mutations on the clinical phenotype of patients, enable functional classification of mutations, enhance diagnostic speed and accuracy and benefit treatment outcome.

Emerging evidence suggests that the interactome of ATP7B under various intra-cellular copper levels might also contribute to variability in molecular phenotype (Polishchuk, Polishchuk 2019). The interdomain and intradomain interactions in ATP7B along with its communications with other interacting proteins during its cellular itinerary shape the complex cellular dynamics of copper homeostasis (Gupta et al. 2018). Dimerization of both wild type and mutant ATP7B has also been reported (Roy et al.2020). A retromer complex containing VPS35 and its associated proteins Rab7A and COMMD1 was shown to retrieve ATP7B from vesicular localization in a copper dependant manner (Das et al. 2020). Hence, mutations in interacting partners that abrogate optimum association between cognate counterparts might affect the molecular phenotype of ATP7B, which needs to be explored further. The observation that the chemotherapeutic drug cisplatin, pharmacological chaperones and microbial peptide can rescue a ATP7B mutant phenotype also holds promise for development of newer drug molecules, ushering in the era of personalised and precision medicine for this disorder, Wilson disease.

\section{Acknowledgements}

The author declares no conflict of interest. The author sincerely thanks the authority of Kalyani Mahavidyalaya for administrative support and cooperation which helped him to pursue studies in this field.

\section{References}

Achila D., Banci L., Bertini I., Bunce J., Ciofi-Baffoni S., Huffman D.L. 2006. Structure of human Wilson protein domains 5 and 6 and their interplay with domain 4 and the copper chaperone HAH1 in copper uptake. Proc. Natl. Acad. Sci. USA 103: 5729-5734.

Aggarwal A., Bhatt M. 2020. Wilson disease. Curr. Opin. Neurol. 33: 534-542.

Aggarwal A., Chandhok G., Todorov T., Parekh S., Tilve S., Zibert A., Bhatt M., Schmidt H.H. 2013. Wilson disease mutation pattern with genotype-phenotype correlations from Western India: confirmation of p.C271* as a common Indian mutation 
and identification of 14 novel mutations. Ann. Human Genet. 77: 299-307.

Allocca S., Ciano M., Ciardulli M.C., D’Ambrosio C., Scaloni A., Sarnataro D., Caporaso M.G., D’Agostino M., Bonatti S. 2018. An aB-crystallin peptide rescues compartmentalization and trafficking response to $\mathrm{Cu}$ overload of ATP7B-H1069Q, the most frequent cause of Wilson disease in the Caucasian population. Int. J. Mol. Sci. 19: 1892.

Anderson G.J., Frazer D.M. 2005. Recent advances in intestinal iron transport. Curr. Gastroenter. Rep. 7: 365-372.

Banci L., Bertini I., Cantini F., Migliardi M., Natile G., Nushi F., Rosato A. 2009. Solution structures of the actuator domain of ATP7A and ATP7B, the Menkes and Wilson disease proteins. Biochemistry 48: 7849-7855.

Barada K., Nemer G., ElHajj I.I., Touma J., Cortas N., Boustany R.M., Usta J. 2007. Early and severe liver disease associated with homozygosity for an exon 7 mutation, G691R, in Wilson's disease. Clin. Genet. 72: 264-267.

Barry A.N., Shinde U., Lutsenko S. 2010. Structural organization of human $\mathrm{Cu}$-transporting ATPases: learning from building blocks. J. Biol. Inorg. Chem. 15: 47-59.

Behari M., Pardasani V. 2010. Genetics of Wilsons disease. Parkinson. Relat. Disord. 16: 639-644.

Braiterman L.T., Murthy A., Jayakanthan S., Nyasae L., Tzeng E., Gromadzka G., Woolf T.B., Lutsenko S., Hubbard A.L. 2014. Distinct phenotype of a Wilson disease mutation reveals a novel trafficking determinant in the copper transporter ATP7B. Proc. Natl. Acad. Sci. USA 111: E1364-E1373.

Braiterman L., Nyasae L., Guo Y., Bustos R., Lutsenko S., Hubbard A. 2009. Apical targeting and Golgi retention signals reside within a 9-amino acid sequence in the copper-ATPase, ATP7B. Am. J. Physiol. Gastrointest. Liver Physiol. 296: G433G444.

Braiterman L., Nyasae L., Leves F., Hubbard A.L. 2011. Critical roles for the COOH terminus of the Cu-ATPase ATP7B in protein stability, trans-Golgi network retention, copper sensing, and retrograde trafficking. Am. J. Physiol. Gastrointest. Liver Physiol. 301: G69-G81.

Bull P.C., Thomas G.R., Rommens J.M., Forbes J.R., Cox D.W. 1993. The Wilson disease gene is a putative copper transporting P-type ATPase similar to the Menkes gene. Nat. Genet. 5: 327-337.

Chandhok G., Horvath J., Aggarwal A., Bhatt M., Zibert A., Schmidt H.H. 2016. Functional analysis and drug response to zinc and D-penicillamine in stable ATP7B mutant hepatic cell lines. World J. Gastroenterol. 22: 4109-4119.

Coffey A.J., Durkie M., Hague S., McLay K., Emmerson J., Lo C., Klaffke S., Joyce C.J., Dhawan A., Hadzic N., Mieli-Vergani G., Kirk R., Allen K.E., Nicholl D., Wong S., Griffiths W., Smithson S., Giffin N., Taha A., Connolly S., Gillett G.T., Tanner S., Bonham J., Sharrack B., Palotie A., Rattray M., Dalton A., Bandmann O. 2013. A genetic study of Wilson's disease in the United Kingdom. Brain 136: 1476-1487.

Członkowska A., Litwin T., Dusek P., Ferenci P., Lutsenko S., Medici V., Rybakowski J.K., Weiss K.H., Schilsky M.L. 2018. Wilson disease. Nat. Rev. Dis. Primers 4: 21.

Das S., Maji S., Ruturaj., Bhattacharya I., Saha T., Naskar N., Gupta A. 2020. Retromer retrieves the Wilson disease protein ATP7B from endolysosomes in a copper-dependent manner. J. Cell. Sci. 133: 246819.

Das SK, Ray K. 2006. Wilson's disease: an update. Nat. Clin. Pract. Neurol. 2: 482-493. de Bie P., Muller P., Wijmenga C., Klomp L.W. 2007a. Molecular pathogenesis of Wilson and Menkes disease: correlation of mutations with molecular defects and disease phenotypes. J. Med. Genet. 44: 673-688.

de Bie P., van de Sluis B., Burstein E., van de Berghe P.V., Muller P., Berger R., Gitlin J.D., Wijmenga C., Klomp L.W. 2007b. Distinct Wilson's disease mutations in ATP7B are associated with enhanced binding to COMMD1 and reduced stability of ATP7B. Gastroenterology 133: 1316-1326.

Deguti M.M., Genschel J., Cancado E.L., Barbosa E.R., Bochow B., Mucenic M., Porta G., Lochs H., Carrilho F.J., Schmidt H.H. 2004. Wilson disease: novel mutations in the ATP7B gene and clinical correlation in Brazilian patients. Hum. Mutat. 23: 698.

Dmitriev O.Y., Bhattacharjee A., Nokhrin S., Uhlemann E.M., Lutsenko S. 2011. Difference in stability of the N-domain underlies distinct intracellular properties of the E1064A and H1069Q mutants of copper-transporting ATPase ATP7B. J. Biol. Chem. 286: 16355-16362.

Dmitriev O., Tsivkovskii R., Abildgaard F., Morgan C.T., Markley J.L., Lutsenko S. 2006. Solution structure of the N-domain of Wilson disease protein: distinct nucleotide-binding environment and effects of disease mutations. Proc. Natl. Acad. Sci. USA 103: 5302-5307.

Erlinger S. 2016. A microbial peptide to rescue severe and fulminant Wilson disease? Clin. Res. Hepatol. Gastroenterol. 40: 647-649.

Ferenci P. 2006. Regional distribution of mutations of the ATP7B gene in patients with Wilson disease: impact on genetic testing. Hum. Genet. 120: 151-159.

Ferenci P., Roberts E.A. 2012. Defining Wilson disease phenotypes: from the patient to the bench and back again. Gastroenterology 142: 692-696.

Figus A., Angius A., Loudianos G., Bertini C., Dessi V., Loi A., Deiana M., Lovicu M., Olla N., Sole G. 1995. Molecular pathology and haplotype analysis of Wilson disease in Mediterranean populations. Am. J. Hum. Genet. 57: 13181324.

Forbes J.R., Cox D.W. 2000. Copper-dependent trafficking of Wilson disease mutant ATP7B proteins. Hum. Mol. Genet. 9: 1927-1935.

Forbes J.R., Cox D.W. 1998. Functional characterization of missense mutations in ATP7B: Wilson disease mutation or normal variant? Am. J. Hum. Genet. 63: 1663-1674.

Gomes A., Dedoussis G.V. 2016. Geographic distribution of ATP7B mutations in Wilson disease. Ann. Hum. Biol. 43: 1-8.

Gourdon P., Liu X.Y., Skjørringe T., Morth J.P., Møller L.B., Pedersen B.P., Nissen P. 2011. Crystal structure of a coppertransporting PIB-type ATPase. Nature 475: 59-64.

Gourdon P., Sitsel O., Karlsen L.J., Møller L.B., Nissen P. 2012. Structural models of the human copper P-type ATPases ATP7A and ATP7B. Biol. Chem. 393: 205-216.

Gromadzka G., Rudnicka M., Chabik G., Przybyłkowski A., Członkowska A. 2011. Genetic variability in the methylenetetrahydrofolate reductase gene (MTHFR) affects clinical expression of Wilson's disease. J. Hepatol. 55: 913-919.

Guo Y., Nyasae L., Braiterman L.T., Hubbard A.L. 2005. NH2terminal signals in ATP7B Cu-ATPase mediate its $\mathrm{Cu}-$ dependent anterograde traffic in polarized hepatic cells. Am. J. Physiol. Gastrointest. Liver Physiol. 289: G904-G916.

Gupta A., Bhattacharjee A., Dmitriev O.Y., Nokhrin S., Braiterman L., Hubbard A.L., Lutsenko S. 2011. Cellular copper levels determine the phenotype of the Arg875 variant of ATP7B/ 
Wilson disease protein. Proc. Natl. Acad. Sci. USA 108: 53905395.

Gupta A., Chattopadhyay I., Dey S., Nasipuri P., Das S.K., Gangopadhyay P.K., Ray K. 2007. Molecular pathogenesis of Wilson disease among Indians: a perspective on mutation spectrum in ATP7B gene, prevalent defects, clinical heterogeneity and implication towards diagnosis. Cell. Mol. Neurobiol. 27: 1023-1033.

Gupta A., Chattopadhyay I., Mukherjee S., Sengupta M., Das S.K., Ray K. 2010. A novel COMMD1 mutation Thr174Met associated with elevated urinary copper and signs of enhanced apoptotic cell death in a Wilson Disease patient. Behav. Brain Funct. 6: 33.

Gupta A., Das S., Ray K. 2018. A glimpse into the regulation of the Wilson disease protein, ATP7B, sheds light on the complexity of mammalian apical trafficking pathways. Metallomics 10 : 378-387.

Hamza I., Schaefer M., Klomp L.W., Gitlin J.D. 1999. Interaction of the copper chaperone HAH1 with the Wilson disease protein is essential for copper homeostasis. Proc. Natl. Acad. Sci. USA 96: 13363-13368.

Hasan N.M., Gupta A., Polishchuk E., Yu C.H., Polishchuk R., Dmitriev O.Y., Lutsenko S. 2012. Molecular events initiating exit of a copper-transporting ATPase ATP7B from the transGolgi network. J. Biol. Chem. 287: 36041-36050.

Hedera P. 2019. Wilson's disease: A master of disguise. Parkinson. Relat. Disord. 59: 140-145.

Hsi G., Cullen L.M., Macintyre G., Chen M.M., Glerum D.M., Cox D.W. 2008. Sequence variation in the ATP-binding domain of the Wilson disease transporter, ATP7B, affects copper transport in a yeast model system. Hum. Mutat. 29: 491-501.

Huster D., Hoppert M., Lutsenko S., Zinke J., Lehmann C., Mössner J., Berr F., Caca K. 2003. Defective cellular localization of mutant ATP7B in Wilson's disease patients and hepatoma cell lines. Gastroenterology 124: 335-345.

Huster D., Kühne A., Bhattacharjee A., Raines L., Jantsch V., Noe J., Schirrmeister W., Sommerer I., Sabri O., Berr F., Mössner J., Stieger B., Caca K., Lutsenko S. 2012. Diverse functional properties of Wilson disease ATP7B variants. Gastroenterology 142: 947-956.

Iida M., Terada K., Sambongi Y., Wakabayashi T., Miura N., Koyama K., Futai M., Sugiyama T. 1998. Analysis of functional domains of Wilson disease protein (ATP7B) in Saccharomyces cerevisiae. FEBS Lett.428: 281-285.

Kaler SG. 2013. Inborn errors of copper metabolism. Handb. Clin. Neurol. 113: 1745-1754.

Karki R., Pandya D., Elston R.C., Ferlini C. 2015. Defining "mutation" and "polymorphism" in the era of personal genomics. BMC Med. Genom. 8: 37.

Kegley K.M., Sellers M.A., Ferber M.J., Johnson M.W., Joelson D.W., Shrestha R. 2010. Fulminant Wilson's disease requiring liver transplantation in one monozygotic twin despite identical genetic mutation. Am. J. Transplant. 10: 1325-1329.

Kenney S.M., Cox D.W. 2007. Sequence variation database for the Wilson disease copper transporter, ATP7B. Hum. Mutat. 28: 1171-1177.

Kim B.E., Nevitt T., Thiele D.J. 2008. Mechanisms for copper acquisition, distribution and regulation. Nat. Chem. Biol. 4: 176-185.

Kumar R., Ariöz C., Li Y., Bosaeus N., Rocha S., WittungStafshede P. 2017. Disease-causing point-mutations in metalbinding domains of Wilson disease protein decrease stability and increase structural dynamics. Biometals 30: 27-35.

Kumari N., Kumar A., Thapa B.R., Modi M., Pal A., Prasad R. 2018. Characterization of mutation spectrum and identification of novel mutations in ATP7B gene from a cohort of Wilson disease patients: Functional and therapeutic implications. Hum. Mutat. 39: 1926-1941.

Kuo Y.M., Gybina A.A., Pyatskowit J.W., Gitschier J., Prohaska J.R. 2006. Copper transport protein (Ctr1) levels in mice are tissue specific and dependent on copper status. J. Nutr. 136: 21-26.

Lalioti V., Muruais G., Tsuchiya Y., Pulido D., Sandoval I.V. 2009. Molecular mechanisms of copper homeostasis. Front. Biosci. 14: 4878-4903.

Langner C., Denk H. 2004. Wilson disease. Virchows Arch. 445: 111-118.

Lee B.H., Kim J.H., Lee S.Y., Jin H.Y., Kim K.J., Lee J.J., Park J.Y., Kim G.H., Choi J.H., Kim K.M., Yoo H.W. 2011. Distinct clinical courses according to presenting phenotypes and their correlations to ATP7B mutations in a large Wilson's disease cohort. Liver Int. 31: 831-839.

Li X., Zhang W., Zhou D., Lv T., Xu A., Wang H., Zhao X., Zhang B., Li Y., Jia S., Wang Y., Wang X., Wu Z., Duan W., Wang Q., Nan Y., Shang J., Jiang W., Chen Y., Zheng S., Liu M., Sun L., You H., Jia J., Ou X., Huang J. 2019. Complex ATP7B mutation patterns in Wilson disease and evaluation of a yeast model for functional analysis of variants. Hum. Mutat. 40: 552-565.

Lichtmannegger J., Leitzinger C., Wimmer R., Schmitt S., Schulz S., Kabiri Y., Eberhagen C., Rieder T., Janik D., Neff F., Straub B.K., Schirmacher P., DiSpirito A.A., Bandow N., Baral B.S., Flatley A., Kremmer E., Denk G., Reiter F.P., Hohenester S., Eckardt-Schupp F., Dencher N.A., Adamski J., Sauer V., Niemietz C., Schmidt H.H., Merle U., Gotthardt D.N., Kroemer G., Weiss K.H., Zischka H. 2016. Methanobactin reverses acute liver failure in a rat model of Wilson disease. J. Clin. Invest. 126: 2721-2735.

Llanos R.M., Mercer J.F. 2002. The molecular basis of copper homeostasis copper-related disorders. DNA Cell Biol. 21: 259-270.

Loudianos G., Dessi V., Lovicu M., Angius A., Figus A., Lilliu F., De Virgiliis S., Nurchi A.M., Deplano A., Moi P., Pirastu M., Cao A. 1999. Molecular characterization of wilson disease in the Sardinian population--evidence of a founder effect. Hum. Mutat. 14: 294-303.

Lovicu M., Dessì V., Lepori M.B., Zappu A., Zancan L., Giacchino R., Marazzi M.G., Iorio R., Vegnente A., Vajro P., Maggiore G., Marcellini M., Barbera C., Kostic V., Farci A.M., Solinas A., Altuntas B., Yuce A., Kocak N., Tsezou A., De Virgiliis S., Cao A., Loudianos G. 2006. The canine copper toxicosis gene MURR1 is not implicated in the pathogenesis of Wilson disease. J. Gastroenterol. 41: 582-587.

Luoma L.M., Deeb T.M., Macintyre G., Cox D.W. 2010. Functional analysis of mutations in the ATP loop of the Wilson disease copper transporter, ATP7B. Hum. Mutat. 31: 569-577.

Lutsenko S. 2014. Modifying factors and phenotypic diversity in Wilson's disease. Ann. NY Acad. Sci. 1315: 56-63.

Lutsenko S., Barnes N.L., Bartee M.Y., Dmitriev O.Y. 2007. Function and regulation of human copper-transporting ATPases. Physiol. Rev. 87: 1011-1046.

Lutsenko S., Gupta A., Burkhead J.L., Zuzel V. 2008. Cellular multitasking: the dual role of human $\mathrm{Cu}$-ATPases in cofactor delivery and intracellular copper balance. Arch. Biochem. Biophys. 476: 22-32.

Majumdar R., Al Jumah M., Fraser M. 2003. 4193delC, a common 
mutation causing Wilson's disease in Saudi Arabia: rapid molecular screening of patients and carriers. Mol. Pathol. 56: 302-304.

McCann C.J., Jayakanthan S., Siotto M., Yang N., Osipova M., Squitti R., Lutsenko S. 2019. Single nucleotide polymorphisms in the human ATP7B gene modify the properties of the ATP7B protein. Metallomics 11: 1128-1139.

Medici V., LaSalle J.M. 2019. Genetics and epigenetic factors of Wilson disease. Ann. Transl. Med. 7: S58.

Medici V., Weiss K.H. 2017. Genetic and environmental modifiers of Wilson disease. Handb. Clin. Neurol. 142: 35-41.

Moini M., To U., Schilsky M.L. 2021. Recent advances in Wilson disease. Transl. Gastroenterol. Hepatol. 6: 21.

Monty J.F., Llanos R.M., Mercer J.F., Kramer D.R. 2005. Copper exposure induces trafficking of the menkes protein in intestinal epithelium of ATP7A transgenic mice. J. Nutr. 135: 2762-2766.

Morgan C.T., Tsivkovskii R., Kosinsky Y.A., Efremov R.G., Lutsenko S. 2004. The distinct functional properties of the nucleotide-binding domain of ATP7B, the human coppertransporting ATPase: analysis of the Wilson disease mutations E1064A, H1069Q, R1151H, and C1104F. J. Biol. Chem. 279: 36363-36371.

Mukherjee S., Dutta S., Majumdar S., Biswas T., Jaiswal P., Sengupta M., Bhattacharya A., Gangopadhyay P.K., Bavdekar A., Das S.K., Ray K. 2014. Genetic defects in Indian Wilson disease patients and genotype-phenotype correlation. Parkinson. Relat. Disord. 20: 75-81.

Nanji M.S., Nguyen V.T., Kawasoe J.H., Inui K., Endo F., Nakajima T., Anezaki T., Cox D.W. 1997. Haplotype and mutation analysis in Japanese patients with Wilson disease. Am. J. Huma.Genet. 60: 1423-1429.

Papur O.S., Terzioglu O., Koc A. 2015. Functional characterization of new mutations in Wilson disease gene (ATP7B) using the yeast model. J. Trace Elem. Med. Biol. 31: 33-36.

Payne A.S., Kelly E.J., Gitlin J.D. 1998. Functional expression of the Wilson disease protein reveals mislocalization and impaired copper-dependent trafficking of the common H1069Q mutation. Proc. Natl. Acad. Sci. USA 95: 10854-10859.

Petrukhin K., Fischer S.G., Pirastu M., Tanzi R.E., Chernov I., Devoto M., Brzustowicz L.M., Cayanis E., Vitale E., Russo J.J. 1993. Mapping, cloning and genetic characterization of the region containing the Wilson disease gene. Nat. Genet. 5: 338-343.

Pilankatta R., Lewis D., Inesi G. 2011. Involvement of protein kinase D in expression and trafficking of ATP7B (copper ATPase). J. Biol. Chem. 286: 7389-7396.

Polishchuk R., Lutsenko S. 2013. Golgi in copper homeostasis: a view from the membrane trafficking field. Histochem. Cell Biol. 140: 285-295.

Polishchuk R.S., Polishchuk E.V. 2019. From and to the Golgi defining the Wilson disease protein road map. FEBS Lett. 593: 2341-2350.

Prohaska J.R. 2008. Role of copper transporters in copper homeostasis. Am. J. Clin. Nutr. 88: 826S-829S.

Purchase R. 2013. The treatment of Wilson's disease, a rare genetic disorder of copper metabolism. Sci. Progr. 96: 19-32.

Quadri M., Federico A., Zhao T., Breedveld G.J., Battisti C., Delnooz C., Severijnen L.A., Mammarella L.D.T., Mignarri A., Monti L., Sanna A., Lu P., Punzo F., Cossu G., Willemsen R., Rasi F., Oostra B.A., van de Warrenburg B.P., Bonifati V. 2012. Mutations in SLC30A10 cause parkinsonism and dystonia with hypermanganesemia, polycythemia, and chronic liver disease. Am. J. Hum. Genet. 90: 467-77.

Roberts E.A. 2018. Update on the diagnosis and management of Wilson disease. Curr. Gastroenterol. Rep. 20: 56.

Roy S., Ganguly K., Pal P., Ghosh S., Das S.K., Gangopadhyay P.K., Bavdekar A., Ray K., Sengupta M., Ray J. 2018. Influence of apolipoprotein E polymorphism on susceptibility of Wilson disease. Ann. Hum. Genet. 82: 53-59.

Roy S., Ghosh S., Bhattacharya S., Saha A., Das S.K., Gangopadhyay P.K., Bavdekar A., Ray K., Sengupta M., Ray J. 2019. Dopamine $\beta$ hydroxylase (DBH) polymorphisms do not contribute towards the clinical course of Wilson's disease in Indian patients. J. Gene Med. 21: e3109.

Roy S., McCann C.J., Ralle M., Ray K., Ray J., Lutsenko S., Jayakanthan S. 2020. Analysis of Wilson disease mutations revealed that interactions between different ATP7B mutants modify their properties. Sci. Rep. 10: 13487.

Roy S., Pal P., Ghosh S., Bhattacharya S., Das S.K., Gangopadhyay P.K., Bavdekar A., Ray K., Sengupta M., Ray J. 2018. Potential role of brain-derived neurotrophic factor and dopamine receptor D2 gene variants as modifiers for the susceptibility and clinical course of Wilson's disease. Neuromol. Med. 20: 401-408.

Schushan M., Bhattacharjee A., Ben-Tal N., Lutsenko S. 2012. A structural model of the copper ATPase ATP7B to facilitate analysis of Wilson disease-causing mutations and studies of the transport mechanism. Metallomics 4: 669-678.

Shah A.B., Chernov I., Zhang H.T., Ross B.M., Das K., Lutsenko S., Parano E., Pavone L., Evgrafov O., Ivanova-Smolenskaya I.A., Annerén G., Westermark K., Urrutia F.H., Penchaszadeh G.K., Sternlieb I., Scheinberg I.H., Gilliam T.C., Petrukhin K. 1997. Identification and analysis of mutations in the Wilson disease gene (ATP7B): population frequencies, genotypephenotype correlation, and functional analyses. Am. J. Hum. Genet. 61: 317-328.

Shanmugavel K.P., Kumar R., Li Y., Wittung-Stafshede P. 2019. Wilson disease missense mutations in ATP7B affect metalbinding domain structural dynamics. Biometals 32: 875-885.

Smirnova J., Kabin E., Järving I., Bragina O., Tõugu V., Plitz T., Palumaa P. 2018. Copper(I)-binding properties of decoppering drugs for the treatment of Wilson disease. $\alpha$-Lipoic acid as a potential anti-copper agent. Sci. Rep. 8: 1463.

Spincemaille P., Pham D.H., Chandhok G., Verbeek J., Zibert A., Libbrecht L., Schmidt H., Esguerra C.V., de Witte P.A., Cammue B.P., Cassiman D., Thevissen K. 2014. The plant decapeptide OSIP108 prevents copper-induced toxicity in various models for Wilson disease. Toxicol. Appl. Pharmacol. 280: 345-351.

Squitti R., Siotto M., Bucossi S., Polimanti R. 2014. In silico investigation of the ATP7B gene: insights from functional prediction of non-synonymous substitution to protein structure. Biometals 27: 53-64.

Stalke A., Pfister E.D., Baumann U., Eilers M., Schäffer V., Illig T., Auber B., Schlegelberger B., Brackmann R., Prokisch H., Krooss S., Bohne J., Skawran B. 2019. Homozygous frame shift variant in ATP7B exon 1 leads to bypass of nonsensemediated mRNA decay and to a protein capable of copper export. Eur. J. Hum. Genet. 27: 879-887.

Steindl P., Ferenci P., Dienes H.P., Grimm G., Pabinger I., Madl C., Maier-Dobersberger T., Herneth A., Dragosics B., Meryn S., Knoflach P., Granditsch G., Gangl A. 1997. Wilson's disease in patients presenting with liver disease: a diagnostic challenge. 
Gastroenterology 113: 212-218.

Thomas G.R., Roberts E.A., Walshe J.M., Cox D.W. 1995. Haplotypes and mutations in Wilson disease. Am. J. Hum. Genet. 56: 1315-1319.

Tsivkovskii R., Eisses J.F., Kaplan J.H., Lutsenko S. 2002. Functional properties of the copper-transporting ATPase ATP7B (the Wilson's disease protein) expressed in insect cells. J. Biol. Chem. 277: 976-983.

van den Berghe P.V., Stapelbroek J.M., Krieger E., de Bie P., van de Graaf S.F., de Groot R.E., van Beurden E., Spijker E., Houwen R.H., Berger R., Klomp L.W. 2009. Reduced expression of ATP7B affected by Wilson disease-causing mutations is rescued by pharmacological folding chaperones 4-phenylbutyrate and curcumin. Hepatology 50: 1783-1795.

Vanderwerf S.M., Cooper M.J., Stetsenko I.V., Lutsenko S. 2001. Copper specifically regulates intracellular phosphorylation of the Wilson's disease protein, a human copper-transporting ATPase. J. Biol. Chem. 276: 36289-36294.

Vrabelova S., Letocha O., Borsky M., Kozak L. 2005. Mutation analysis of the ATP7B gene and genotype/phenotype correlation in 227 patients with Wilson disease. Mol. Genet. Metabol. 86: 277-285.

Wallace D.F., Dooley J.S. 2020. ATP7B variant penetrance explains differences between genetic and clinical prevalence estimates for Wilson disease. Human Genet. 139: 1065-1075.

Wang C., Zhou W., Huang Y., Yin H., Jin Y., Jia Z., Zhang A., Liu Z., Zheng B. 2018. Presumed missense and synonymous mutations in ATP7B gene cause exon skipping in Wilson disease. Liver Int. 38: 1504-1513.

Wilson S.A.K. 1912. Progressive lenticular degeneration: a familial nervous disease associated with cirrhosis of the liver. Brain 34: 296-507.

Yi F., Poskanzer S.A., Myers C.T., Thies J., Collins C.J., Dayuha R., Duong P., Houwen R., Hahn S.H. 2020. p.P1379S, a benign variant with reduced ATP7B protein level in Wilson Disease. JIMD Rep. 54: 32-36.

Yu C.H., Dolgova N.V., Dmitriev O.Y. 2017. Dynamics of the metal binding domains and regulation of the human copper transporters ATP7B and ATP7A. IUBMB Life 69: 226-235.

Zhou X., Zhou W., Wang C., Wang L., Jin Y., Jia Z., Liu Z., Zheng B. 2021. A comprehensive analysis and splicing characterization of naturally occurring synonymous variants in the ATP7B gene. Front. Genet. 11: 592611.

Zhu M., Dong Y., Ni W., Wu Z.Y. 2015. Defective roles of ATP7B missense mutations in cellular copper tolerance and copper excretion. Mol. Cell. Neurosci. 67: 31-36.

Appendix 1. Diverse cellular properties of ATP7B on account of missense mutations. Data acquired through Pubmed search using keywords ATP7B, Wilson Disease and, WD. ${ }^{\star}$ Data for exploration of all properties for every single mutant is currently not available (--). For this table, only missense mutants are considered. Few representative in/del and engineered mutations are incorporated for comparison purpose only. Yeast assays, though not very sensitive, are included to draw a composite view; In-silico findings are beyond the scope of this discussion and hence not included. \#Inclusive of ATP binding/catalytic or kinase mediated phosphorylation, cuproenzyme biosynthesis, copper transport, stability, and biochemical/structural properties regulating key functionalities etc. Retrograde trafficking has not been explored for most of the mutants. $†$ Residues fall within $\mathrm{N}$-terminal 9 amino acid signal sequence F37AFDNVGYE45 which participates in TGN retention during low $\mathrm{Cu}$ and apical targeting at elevated Cu levels. TGN, trans-Golgi network; ER, endoplasmin reticulum; MBD, metal binding domain (also CuBD); TM, transmembrane domain; NBD, nucleotide binding and phosphorylation domain

\begin{tabular}{|c|c|c|c|c|c|}
\hline No. & Mutants & $\begin{array}{l}\text { Protein } \\
\text { domain }\end{array}$ & Impact on localization/trafficking* & $\begin{array}{l}\text { Impact on catalytic/ } \\
\text { biosynthetic and transport } \\
\text { related properties etc. }{ }^{*} \#\end{array}$ & References \\
\hline 1 & p.N41S $\dagger$ & N-terminal & $\begin{array}{l}\text { Diminished retention in TGN; } \\
\text { constitutive mis-sorting to basolateral } \\
\text { membrane in copper depleted condition }\end{array}$ & Normal cuproenzyme biosynthesis & $\begin{array}{l}\text { Braiterman et al. } \\
2009\end{array}$ \\
\hline 2 & p.Y44A/F $\dagger$ & N-terminal & $\begin{array}{l}\text { Diminished retention in TGN; } \\
\text { constitutive mis-sorting to basolateral } \\
\text { membrane in copper depleted condition } \\
\text { (p.Y44A); normal localization and } \\
\text { anterograde trafficking behaviour } \\
\text { (p.Y44F) }\end{array}$ & $\begin{array}{l}\text { Normal cuproenzyme biosynthesis } \\
\text { for both }\end{array}$ & $\begin{array}{l}\text { Braiterman et al. } \\
2009\end{array}$ \\
\hline 3 & p.G85V & MBD1 & $\begin{array}{l}\text { Extensive ER mislocalization in basal } \\
\text { condition }\end{array}$ & $\begin{array}{l}\text { Completely impaired catalytic } \\
\text { phosphorylation; defective copper } \\
\text { transport across membrane, partial/ } \\
\text { no yeast rescue, reduced stability, } \\
\text { misfolding }\end{array}$ & $\begin{array}{l}\text { de Bie et al. 2007b; } \\
\text { Huster et al. 2012; } \\
\text { Kumar et al. 2017; } \\
\text { Li et al. } 2019\end{array}$ \\
\hline 4 & p.L492S & MBD5 & Trapped in ER (yeast) & No yeast rescue & $\begin{array}{l}\text { Shanmugavel et al. } \\
2019\end{array}$ \\
\hline 5 & p.Y532H & MBD5 & -- & Normal yeast complementation & His et al. 2008 \\
\hline 6 & p. P534T & MBD5 & -- & $\begin{array}{l}\text { Augmented } \mathrm{Cu} \text { retention, decreased } \\
\text { ceruloplasmin secretion }\end{array}$ & Kumari et al. 2018 \\
\hline 7 & p.P539H & MBD5 & -- & $\begin{array}{l}\text { Augmented } \mathrm{Cu} \text { retention, decreased } \\
\text { ceruloplasmin secretion }\end{array}$ & Kumari et al. 2018 \\
\hline
\end{tabular}


Appendix 1. Continued

\begin{tabular}{|c|c|c|c|c|c|}
\hline No. & Mutants & $\begin{array}{l}\text { Protein } \\
\text { domain }\end{array}$ & Impact on localization/trafficking* & $\begin{array}{l}\text { Impact on catalytic/ } \\
\text { biosynthetic and transport } \\
\text { related properties etc. }{ }^{*} \#\end{array}$ & References \\
\hline 8 & p.G591D & MBD6 & $\begin{array}{l}\text { Extensive ER mislocalization in basal } \\
\text { condition }\end{array}$ & $\begin{array}{l}\text { Impaired copper induced kinase } \\
\text { mediated phosphorylation, reduced } \\
\text { stability, misfolding }\end{array}$ & $\begin{array}{l}\text { de Bie et al. 2007b; } \\
\text { Vanderwerf et al. } \\
\text { 2001; Kumar et al. } \\
2017\end{array}$ \\
\hline 9 & p.A595T & MBD6 & $\begin{array}{l}\text { Normal TGN localization in basal } \\
\text { condition and responsive to copper } \\
\text { induced anterograde trafficking. Normal } \\
\text { retrograde movement }\end{array}$ & $\begin{array}{l}\text { Diminished } \mathrm{Cu} \text { transport activity, } \\
\text { enhanced } \mathrm{Cu} \text { retention but normal } \\
\text { protein abundance }\end{array}$ & Roy et al. 2020 \\
\hline 10 & p.A604P & MBD6 & -- & Partial yeast rescue & $\begin{array}{l}\text { Shanmugavel et al., } \\
2019\end{array}$ \\
\hline 11 & p.R616W/ Q & MBD6 & $\begin{array}{l}\text { Normal TGN localization in basal } \\
\text { condition (R616W) }\end{array}$ & $\begin{array}{l}\text { Low copper transport rate } \\
\text { across membrane; No yeast } \\
\text { rescue, normal ATP binding and } \\
\text { hydrolysis; partially impaired } \\
\text { dephosphorylation (R616W); } \\
\text { partial/ no yeast rescue (R616Q) }\end{array}$ & $\begin{array}{l}\text { Huster et al. 2003; } \\
\text { 2012; Shanmugavel } \\
\text { et al. 2019; Li et al. } \\
2019\end{array}$ \\
\hline 12 & p. G626A & MBD6 & -- & Normal yeast rescue & $\begin{array}{l}\text { Shanmugavel et } \\
\text { al. 2019; Hsi et al. } \\
2008\end{array}$ \\
\hline 13 & p.D642Y/H & $\begin{array}{l}\text { Between } \\
\text { MBD6 and } \\
\text { TM1 }\end{array}$ & -- & $\begin{array}{l}\text { Augmented Cu retention, decreased } \\
\text { ceruloplasmin secretion (D642Y); } \\
\text { Normal yeast rescue (D642H) }\end{array}$ & $\begin{array}{l}\text { Kumari et al. 2018; } \\
\text { Hsi et al. } 2008\end{array}$ \\
\hline 14 & p.M645R & $\begin{array}{l}\text { Between } \\
\text { MBD6 and } \\
\text { TM1 }\end{array}$ & -- & Normal Cu transport & $\begin{array}{l}\text { Schushan et al. } \\
\text { 2012; Huster et al. } \\
2012\end{array}$ \\
\hline 15 & p.S653Y & $\begin{array}{l}\text { Between } \\
\text { MBD6 and } \\
\text { TM1 }\end{array}$ & Disrupted $\mathrm{Cu}$ responsive trafficking & Normal Cu transport & $\begin{array}{l}\text { Braiterman et al. } \\
2014\end{array}$ \\
\hline 16 & p.G710S & TM2 & $\begin{array}{l}\text { Normal TGN localization in basal } \\
\text { condition }\end{array}$ & $\begin{array}{l}\text { Low copper transport rate across } \\
\text { membrane, normal ATP binding } \\
\text { and hydrolysis }\end{array}$ & $\begin{array}{l}\text { Huster et al. 2003; } \\
2012\end{array}$ \\
\hline 17 & p.G711R/W/E & TM2 & -- & $\begin{array}{l}\text { In-vivo study in mouse model } \\
\text { showing hepatic overload and } \\
\text { elevated Cu in brain }\end{array}$ & $\begin{array}{l}\text { Schushan et al. } \\
2012\end{array}$ \\
\hline 18 & p.R723T & $\begin{array}{l}\text { Between } \\
\text { TM } 2 / 3\end{array}$ & -- & $\begin{array}{l}\text { Augmented } \mathrm{Cu} \text { retention, decreased } \\
\text { ceruloplasmin secretion }\end{array}$ & Kumari et al. 2018 \\
\hline 19 & p.R725T & $\begin{array}{l}\text { Between } \\
\text { TM } 2 / 3\end{array}$ & -- & $\begin{array}{l}\text { Augmented } \mathrm{Cu} \text { retention, decreased } \\
\text { ceruloplasmin secretion }\end{array}$ & Kumari et al. 2018 \\
\hline 20 & p.Y741C & TM3 & -- & partial/ no yeast rescue & Li et al. 2019 \\
\hline 21 & p.L745R & TM3 & -- & partial/ no yeast rescue & Li et al. 2019 \\
\hline 22 & p.P760L & $\begin{array}{l}\text { luminal } \\
\text { loop } 2\end{array}$ & $\begin{array}{l}\text { Normal TGN localization in basal } \\
\text { condition }\end{array}$ & $\begin{array}{l}\text { Low copper transport rate across } \\
\text { membrane; normal ATP binding } \\
\text { and hydrolysis; partially impaired } \\
\text { dephosphorylation }\end{array}$ & $\begin{array}{l}\text { Huster et al. 2003; } \\
2012\end{array}$ \\
\hline 23 & p.D765N & TM4 & $\begin{array}{l}\text { Aberrant, clustered near nucleus in basal } \\
\text { condition }\end{array}$ & $\begin{array}{l}\text { Partial copper transport rate across } \\
\text { membrane; normal ATP binding } \\
\text { and hydrolysis; partially impaired } \\
\text { dephosphorylation; normal yeast } \\
\text { rescue }\end{array}$ & $\begin{array}{l}\text { Forbes, Cox 1998; } \\
\text { Huster et al. 2003; } \\
2012\end{array}$ \\
\hline 24 & p.M769V & TM4 & $\begin{array}{l}\text { Normal TGN localization in basal } \\
\text { condition and responsive to copper } \\
\text { induced anterograde trafficking }\end{array}$ & $\begin{array}{l}\text { Partial copper transport rate across } \\
\text { membrane; normal ATP binding } \\
\text { and hydrolysis, partially impaired } \\
\text { dephosphorylation; yeast rescue } \\
\text { at lower temperature (temperature } \\
\text { sensitive) }\end{array}$ & $\begin{array}{l}\text { Forbes, Cox 1998; } \\
\text { 2000; Huster et al. } \\
\text { 2003; } 2012\end{array}$ \\
\hline 25 & p.R778L/Q & TM4 & $\begin{array}{l}\text { Extensive ER mislocalization in basal } \\
\text { condition (p.R778L) }\end{array}$ & $\begin{array}{l}\text { Weak yeast rescue (p.R778L); } \\
\text { enhanced Cu accumulation in cell, } \\
\text { partial yeast rescue (p.R778Q) } \\
\text { suggesting residual copper- } \\
\text { translocating activity }\end{array}$ & $\begin{array}{l}\text { Forbes, Cox 1998; } \\
\text { 2000; Zhu et al. } \\
2015\end{array}$ \\
\hline
\end{tabular}


Appendix 1. Continued

\begin{tabular}{|c|c|c|c|c|c|}
\hline No. & Mutants & $\begin{array}{l}\text { Protein } \\
\text { domain }\end{array}$ & Impact on localization/trafficking* & $\begin{array}{l}\text { Impact on catalytic/ } \\
\text { biosynthetic and transport } \\
\text { related properties etc. }{ }^{\star} \#\end{array}$ & References \\
\hline 26 & p.T788I & A-domain & -- & Partial yeast rescue & Papur et al. 2015 \\
\hline 27 & p.K832R & A-domain & Diminished trafficking at elevated $\mathrm{Cu}$ & $\begin{array}{l}\text { Lower protein abundance, lower } \\
\text { copper transport activity at K952 } \\
\text { background, partial/ no yeast rescue }\end{array}$ & $\begin{array}{l}\text { McCann et al. } \\
\text { 2019; Li et al. } 2019\end{array}$ \\
\hline 28 & p.P840L & A-domain & -- & Highly diminished $\mathrm{Cu}$ transport & $\begin{array}{l}\text { Huster et al. 2012; } \\
\text { Schushan et al. } \\
2012\end{array}$ \\
\hline 29 & p.I857T & A-domain & -- & $\begin{array}{l}\text { Diminished Cu transport, inhibited } \\
\text { catalytic dephosphorylation }\end{array}$ & Huster et al. 2012 \\
\hline 30 & p.A874V & A-domain & ER retained & $\begin{array}{l}\text { Lacks activity, diminished } \mathrm{Cu} \\
\text { transport, partial/ no yeast rescue }\end{array}$ & $\begin{array}{l}\text { Huster et al. 2012, } \\
\text { Schushan et al. } \\
\text { 2012; Li et al. } 2019\end{array}$ \\
\hline 31 & p.G875R & A-domain & $\begin{array}{l}\text { Normal localization at elevated copper } \\
\text { levels but retained in ER at basal } \\
\text { conditions }\end{array}$ & $\begin{array}{l}\text { Normal Cu transport but decreased } \\
\text { affinity for ATP, destabilised } \\
\text { A-domain }\end{array}$ & Gupta et al. 2011 \\
\hline 32 & p.R919G & A-domain & $\begin{array}{l}\text { Normal localisation but defective } \\
\text { anterograde trafficking }\end{array}$ & $\begin{array}{l}\text { Cell survival mildly affected on } \mathrm{Cu} \\
\text { overload }\end{array}$ & Zhu et al. 2015 \\
\hline 33 & p.1929V & TM5 & -- & Normal yeast rescue. & $\begin{array}{l}\text { Schushan et al. } \\
2012\end{array}$ \\
\hline 34 & p.T935M & TM5 & Normal localisation and trafficking & $\begin{array}{l}\text { Cell survival mildly affected on } \mathrm{Cu} \\
\text { overlaod }\end{array}$ & Zhu et al. 2015 \\
\hline 35 & p.G943S & $\begin{array}{l}\text { 3rd luminal } \\
\text { loop }\end{array}$ & $\begin{array}{l}\text { Normal TGN localization but } \\
\text { unresponsive to copper induced } \\
\text { anterograde trafficking. }\end{array}$ & Normal yeast rescue & $\begin{array}{l}\text { Forbes, Cox 1998; } \\
2000\end{array}$ \\
\hline 36 & p.R952K & $\begin{array}{l}\text { 3rd luminal } \\
\text { loop }\end{array}$ & $\begin{array}{l}\text { Both TGN and vesicles under low } \mathrm{Cu} \text { at } \\
\text { R832 background }\end{array}$ & $\begin{array}{l}\text { Diminished } \mathrm{Cu} \text { transport at K832 } \\
\text { background }\end{array}$ & McCann et al. 2019 \\
\hline 37 & p.R969Q & $\begin{array}{l}\text { 3rd luminal } \\
\text { loop }\end{array}$ & $\begin{array}{l}\text { Normal TGN localization in basal } \\
\text { condition }\end{array}$ & $\begin{array}{l}\text { Partial copper transport rate across } \\
\text { membrane; normal ATP binding } \\
\text { and hydrolysis, partially impaired } \\
\text { dephosphorylation }\end{array}$ & $\begin{array}{l}\text { Huster et al. 2003; } \\
2012\end{array}$ \\
\hline 38 & p.T977M & TM6 & -- & No yeast rescue & $\begin{array}{l}\text { Forbes, Cox et al. } \\
1998\end{array}$ \\
\hline 39 & p.T991M & TM6 & -- & Partial yeast rescue & Luoma et al. 2010 \\
\hline 40 & p.P992L & TM6 & $\begin{array}{l}\text { Normal TGN localization in basal } \\
\text { condition, impaired trafficking }\end{array}$ & $\begin{array}{l}\text { Normal ATP binding and } \\
\text { hydrolysis; defective copper } \\
\text { transport across membrane; } \\
\text { reduced yeast rescue, Cu retention } \\
\text { in cells }\end{array}$ & $\begin{array}{l}\text { Forbes, Cox 1998; } \\
\text { Huster et al. 2003; } \\
\text { Zhu et al. } 2015\end{array}$ \\
\hline 41 & p.V995A & TM6 & -- & Normal yeast phenotype & $\begin{array}{l}\text { Schushan et al. } \\
\text { 2012; Forbes, Cox } \\
1998\end{array}$ \\
\hline 42 & p.G1000R & NBD & -- & No yeast rescue & Luoma et al. 2010 \\
\hline 43 & p.D1027A & NBD & $\begin{array}{l}\text { Normal TGN localization; but } \\
\text { unresponsive to copper induced } \\
\text { anterograde trafficking }\end{array}$ & $\begin{array}{l}\text { Catalytically inactive; completely } \\
\text { impaired copper transport across } \\
\text { membrane }\end{array}$ & $\begin{array}{l}\text { Dmitriev et al. } \\
\text { 2011; Huster et al. } \\
\text { 2012; Polishchuk, } \\
\text { Lutsenko } 2013\end{array}$ \\
\hline 44 & p.T1031S & NBD & -- & Highly diminished $\mathrm{Cu}$ transport & $\begin{array}{l}\text { Schushan et al. } \\
\text { 2012; Huster et al. } \\
2012\end{array}$ \\
\hline 45 & p.V1036I & NBD & -- & Partial yeast rescue & Papur et al. 2015 \\
\hline 46 & p.R1038G-fsX83 & NBD & -- & No yeast rescue & Papur et al. 2015 \\
\hline 47 & p.R1041W/P & NBD & -- & Normal yeast rescue & $\begin{array}{l}\text { Schushan et al. } \\
\text { 2012; His et al. } \\
2008\end{array}$ \\
\hline 48 & p.L1043P & & -- & No yeast rescue & Luoma et al. 2010 \\
\hline 49 & p.P1052L & NBD & -- & $\begin{array}{l}\text { Highly diminished } \mathrm{Cu} \text { transport but } \\
\text { normal catalytic phosphorylation }\end{array}$ & $\begin{array}{l}\text { Schushan et al. } \\
\text { 2012; Huster et al. } \\
2012\end{array}$ \\
\hline
\end{tabular}


Appendix 1. Continued

\begin{tabular}{|c|c|c|c|c|c|}
\hline No. & Mutants & $\begin{array}{l}\text { Protein } \\
\text { domain }\end{array}$ & Impact on localization/trafficking* & $\begin{array}{l}\text { Impact on catalytic/ } \\
\text { biosynthetic and transport } \\
\text { related properties etc. }{ }^{\star} \#\end{array}$ & References \\
\hline 50 & p.G1061E & NBD & ER retention & $\begin{array}{l}\text { Inhibited } \mathrm{Cu} \text { transport and } \\
\text { diminished protein abundance, } \\
\text { enhanced } \mathrm{Cu} \text { retention }\end{array}$ & Roy et al. 2020 \\
\hline 51 & p.E1064A & NBD & Normal TGN localization. & $\begin{array}{l}\text { Drastically reduced affinity for } \\
\text { ATP; absence of ATP binding due } \\
\text { to misalignment of domains but } \\
\text { stability not impaired, No yeast } \\
\text { complementation }\end{array}$ & $\begin{array}{l}\text { Morgan et al. 2004; } \\
\text { His et al. 2008; } \\
\text { Dmitriev et al. } \\
\text { 2011; Polishchuk, } \\
\text { Lutsenko } 2013\end{array}$ \\
\hline 52 & p.E1064K & NBD & -- & No yeast complementation & Hsi et al. 2008 \\
\hline 53 & p.H1069Q & NBD & $\begin{array}{l}\text { Extensive ER mislocaization (normal } \\
\text { TGN localization at lower temperature) }\end{array}$ & $\begin{array}{l}\text { Drastically reduced affinity for ATP; } \\
\text { disrupted ATP binding and catalytic } \\
\text { phosphorylation; stability greatly } \\
\text { compromised; minimal copper } \\
\text { transport activity; weak yeast rescue }\end{array}$ & $\begin{array}{l}\text { Iida et al. 1998; } \\
\text { Payne et al. 1998; } \\
\text { Forbes, Cox 2000; } \\
\text { Morgan et al. 2004; } \\
\text { Dmitriev et al. } \\
2011\end{array}$ \\
\hline 54 & p.L1083F & NBD & -- & No yeast complementation & Hsi et al. 2008 \\
\hline 55 & p.G1101R & NBD & ER retention & $\begin{array}{l}\text { Inhibited } \mathrm{Cu} \text { transport and } \\
\text { diminished protein abundance, } \\
\text { enhanced } \mathrm{Cu} \text { retention, No yeast } \\
\text { rescue }\end{array}$ & $\begin{array}{l}\text { Roy et al. } 2020 \text {; } \\
\text { Luoma et al. } 2010\end{array}$ \\
\hline 56 & p.I1102T & NBD & -- & $\mathrm{No} /$ partial yeast rescue & Luoma et al. 2010 \\
\hline 57 & p.C1104F/A & NBD & -- & $\begin{array}{l}\text { Significantly altered protein folding } \\
\text { (p.C1104F); structure or function } \\
\text { of nucleotide binding domain } \\
\text { unaffected (p.C1104A) }\end{array}$ & Morgan et al. 2004 \\
\hline 58 & p.V1106D & NBD & -- & No yeast rescue & $\begin{array}{l}\text { Hsi et al. 2008; } \\
\text { Schushan et al. } \\
2012\end{array}$ \\
\hline 59 & p.A1140V & NBD & -- & Normal yeast rescue & $\begin{array}{l}\text { Hsi et al. 2008; } \\
\text { Schushan et al. } \\
2012\end{array}$ \\
\hline 60 & p.I1148T & NBD & & Partial yeast rescue & Luoma et al. 2010 \\
\hline 61 & p.R1151H & NBD & -- & Slightly reduced affinity for ATP. & Morgan et al. 2004 \\
\hline 62 & p.M1169V & NBD & -- & Partial yeast rescue & Hsi et al. 2008 \\
\hline 63 & p.E1173G & NBD & -- & Normal yeast complementation & Luoma et al. 2010 \\
\hline 64 & p.G1176E & NBD & -- & Partial yeast rescue & Luoma et al. 2010 \\
\hline 65 & p.A1183T/G & NBD & -- & Normal yeast rescue & $\begin{array}{l}\text { Hsi G et al. 2008; } \\
\text { Schushan et al. } \\
2012\end{array}$ \\
\hline 66 & p.G1186S/C & NBD & -- & Normal yeast rescue & $\begin{array}{l}\text { His et al. 2008; } \\
\text { Schushan et al. } \\
2012\end{array}$ \\
\hline 67 & p.G1287S & NBD & -- & Partial yeast rescue & Luoma et al. 2010 \\
\hline 68 & p.G1213V & NBD & -- & Complete inability of $\mathrm{Cu}$ transport & $\begin{array}{l}\text { Huster et al. 2012; } \\
\text { Schushan et al. } \\
2012\end{array}$ \\
\hline 69 & p.D1222V & NBD & -- & Highly diminished $\mathrm{Cu}$ transport & $\begin{array}{l}\text { Huster et al. 2012; } \\
\text { Schushan et al. } \\
2012\end{array}$ \\
\hline 70 & p.R1228T & NBD & -- & Normal yeast rescue & Luoma et al. 2010 \\
\hline 71 & p.I1230T & NBD & -- & partial/ no yeast rescue & Li et al. 2019 \\
\hline 72 & p.V1239G & NBD & -- & no yeast rescue & Luoma et al. 2010 \\
\hline 73 & p.V1262F & NBD & -- & Perturbed folding & $\begin{array}{l}\text { Forbes, Cox 1998; } \\
\text { Schushan et al. } \\
2012\end{array}$ \\
\hline 74 & p.G1266R & NBD & -- & Highly diminished $\mathrm{Cu}$ transport & $\begin{array}{l}\text { Huster et al. 2012; } \\
\text { Schushan et al. } \\
2012\end{array}$ \\
\hline
\end{tabular}




\section{Appendix 1. Continued}

\begin{tabular}{|c|c|c|c|c|c|}
\hline No. & Mutants & $\begin{array}{l}\text { Protein } \\
\text { domain }\end{array}$ & Impact on localization/trafficking* & $\begin{array}{l}\text { Impact on catalytic/ } \\
\text { biosynthetic and transport } \\
\text { related properties etc. }{ }^{*} \#\end{array}$ & References \\
\hline 75 & p.D1267V & NBD & -- & no yeast rescue & Luoma et al. 2010 \\
\hline 76 & p.N1270S & NBD & $\begin{array}{l}\text { Normal TGN localization in basal } \\
\text { condition }\end{array}$ & $\begin{array}{l}\text { Completely impaired copper } \\
\text { transport across membrane, } \\
\text { significantly reduced copper } \\
\text { stimulated ATPase activity; No yeast } \\
\text { rescue }\end{array}$ & $\begin{array}{l}\text { Shah et al. 1997; } \\
\text { Huster et al. } 2012\end{array}$ \\
\hline 77 & p.R1301Q & NBD & -- & partial/ no yeast rescue & Li et al. 2019 \\
\hline 78 & p.M1359I & TM8 & -- & $\begin{array}{l}\text { Hepatic copper overload in mice } \\
\text { model, highly diminished copper } \\
\text { transport activity }\end{array}$ & $\begin{array}{l}\text { Schushan et al. } \\
2012\end{array}$ \\
\hline 79 & p.S1362A & TM8 & $\begin{array}{l}\text { Normal TGN localization but } \\
\text { unresponsive to copper induced } \\
\text { anterograde trafficking. }\end{array}$ & $\begin{array}{l}\text { Diminished } \mathrm{Cu} \text { transport activity, } \\
\text { enhanced } \mathrm{Cu} \text { retention, but normal } \\
\text { protein level }\end{array}$ & Roy et al. 2020 \\
\hline 80 & p.S1363F & TM8 & -- & Perturbed folding & $\begin{array}{l}\text { Forbes, Cox 1998; } \\
\text { Schushan et al. } \\
2012\end{array}$ \\
\hline 81 & p.L1373P/R & $\begin{array}{l}\text { Between } \\
\text { TM8/C- } \\
\text { terminal tail }\end{array}$ & $\begin{array}{l}\text { Both mutants failed to be retained in } \\
\text { the TGN in basal condition with apical } \\
\text { vesicular and diffused cytoplasmic } \\
\text { localization }\end{array}$ & $\begin{array}{l}\text { Normal cuproenzyme biosynthesis } \\
\text { (p.L1373P); partial cuproenzyme } \\
\text { biosynthesis (p.L1373R); decreased } \\
\text { stability for both mutants }\end{array}$ & $\begin{array}{l}\text { Braiterman et al. } \\
2011 \text {, Huster et al. } \\
2012\end{array}$ \\
\hline 82 & p.1379S & $\begin{array}{l}\text { C-terminal } \\
\text { tail }\end{array}$ & -- & Highly diminished protein level & Yi et al. 2020 \\
\hline 83 & $\begin{array}{l}\text { p.Q1399Rfs (lacks } \\
\text { trileucine motif) } \\
\text { [truncated] }\end{array}$ & $\begin{array}{l}\text { C-terminal } \\
\text { tail }\end{array}$ & $\begin{array}{l}\text { Near-normal TGN retention and wild- } \\
\text { type outward (anterograde) trafficking; } \\
\text { defective retrograde trafficking on } \\
\text { copper depletion }\end{array}$ & Normal cuproenzyme biosynthesis & $\begin{array}{l}\text { Braiterman et al. } \\
2011\end{array}$ \\
\hline 84 & $\begin{array}{l}\text { p.W1410X (lacks } \\
\text { trileucine motif) } \\
\text { [truncated] }\end{array}$ & $\begin{array}{l}\text { C-terminal } \\
\text { tail }\end{array}$ & $\begin{array}{l}\text { Near-normal TGN retention and wild- } \\
\text { type outward (anterograde) trafficking; } \\
\text { defective retrograde trafficking on } \\
\text { copper depletion }\end{array}$ & Normal cuproenzyme biosynthesis & $\begin{array}{l}\text { Braiterman et al. } \\
2011\end{array}$ \\
\hline 85 & p.S1426I & $\begin{array}{l}\text { C-terminal } \\
\text { tail }\end{array}$ & $\begin{array}{l}\text { Normal TGN localization in basal } \\
\text { condition and normal anterograde and } \\
\text { retrograde trafficking }\end{array}$ & $\begin{array}{l}\text { Diminished } \mathrm{Cu} \text { transport activity, } \\
\text { enhanced } \mathrm{Cu} \text { retention }\end{array}$ & Roy et al. 2020 \\
\hline 86 & $\begin{array}{l}\text { p.P1438Afs (lacks } \\
\text { trileucine motif) } \\
\text { [truncated] }\end{array}$ & $\begin{array}{l}\text { C-terminal } \\
\text { tail }\end{array}$ & $\begin{array}{l}\text { Near-normal TGN retention and wild- } \\
\text { type outward (anterograde) trafficking; } \\
\text { defective retrograde trafficking on } \\
\text { copper depletion }\end{array}$ & Normal cuproenzyme biosynthesis & $\begin{array}{l}\text { Braiterman et al. } \\
2011\end{array}$ \\
\hline 87 & $\begin{array}{l}\text { p.S478/481/1121/ } \\
\text { 1453A (engineered) }\end{array}$ & $\begin{array}{l}\text { Between } \\
\text { MBD4-5/ } \\
\text { MBD4-5/ } \\
\text { NBD/C- } \\
\text { terminal tail }\end{array}$ & $\begin{array}{l}\text { Constitutively retained in TGN in both } \\
\text { low and high copper }\end{array}$ & $\begin{array}{l}\text { Impaired copper induced kinase } \\
\text { mediated phosphorylation }\end{array}$ & $\begin{array}{l}\text { Pilankatta et al. } \\
2011\end{array}$ \\
\hline
\end{tabular}

